\title{
GLOBAL STANDARD-SETTING 2.0: HOW THE WTO SPOTLIGHTS ISO AND IMPACTS THE TRANSNATIONAL STANDARD-SETTING PROCESS
}

\author{
PANAGIOTIS DELIMATSIS*
}

\begin{abstract}
Transnational technical standard-setting has grown in prominence in recent years. The World Trade Organization (WTO) requires the use of international standards but adopts a deferential approach towards international standards. However, practice shows that several international standards are promulgated through opaque and exclusionary processes. In line with this observation, in its recent US - Tuna II ruling, the Appellate Body adopted a more critical stance regarding international standards and the processes that lead to their adoption. Against this backdrop, this article focuses on an analysis of the properties and mechanics of international standard-setting processes within the International Organization for Standardization (ISO), discussing procedural and substantive guarantees regarding transparency, openness, deliberation and participation. As the WTO becomes the de facto arbiter of the legitimacy of international standards, much needed institutional reform in international standardsetting is bound to occur. Arguably, this is bringing a paradigm shift in standardization practices and introduces "global standard-setting 2.0." Such trend is in line with emerging demands for a more inclusive global legal order.
\end{abstract}

Copyright (C) 2018 Panagiotis Delimatsis

* Professor of European and International Trade Law and Director, Tilburg Law and Economics Center (TILEC), Tilburg University, the Netherlands. An early version of this article was presented at the biennial conference of the Society of International Economic Law in Bern in July 2014 and benefited from insightful comments by the participants. An updated draft was presented in the conference on 'Standards, Regulation and (Transatlantic) Trade Integration' in Florence in November 2014 and at the author's keynote speech at the University of Helsinki in November 2016. The author would like to thank in particular Alessandra Arcuri, Axel Marx, Jens Prüfer, Petros Mavroidis, Charles Sabel, Harm Schepel, Philip Schleifer, Reinhard Weissinger, and Erik Wijkström. For its research on competition, standardization, and innovation, TILEC has received funding from Qualcomm Inc., which is gratefully acknowledged. The research on which this article is based was conducted in accordance with the rules set out in the Royal Dutch Academy of Sciences (KNAW) Declaration of Scientific Independence. Any remaining errors or misconceptions are the author's alone. Contact: p.delimatsis@uvt.nl. 


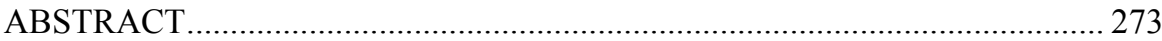

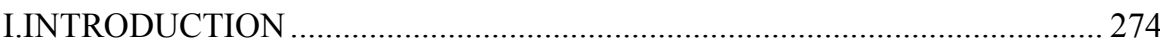

II.INTERNATIONAL STANDARDS AND THE TBT .................................. 278

A. Technical Regulations and (International) Standards under the TBT

B. Standardizing Organizations and "Recognized" Bodies ................. 281

C. Upgrading the TBT Committee Decision ........................................ 284

D. Interim Conclusion.......................................................................... 285

III.PROCEDURAL AND SUBSTANTIVE SAFEGUARDS IN ISO................. 286

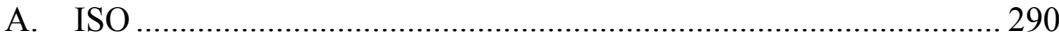

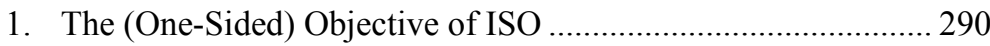

2. ISO Membership.................................................................... 291

B. Standard-Setting Process in ISO .................................................... 294

1. The Understated Political Element of ISO Standard-Setting ..... 294

2. The Various Stages of Standard-Setting within ISO.................. 294

3. Collaborative International Standard-Setting............................ 299

C. Consensus Building in ISO ........................................................... 300

D. Other Procedural and Substantive Guarantees .................................. 302

IV.AN ASSESSMENT OF ISO'S STANDARDIZATION-RELATED

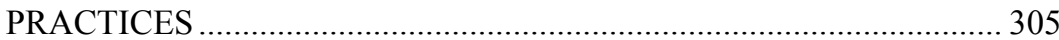

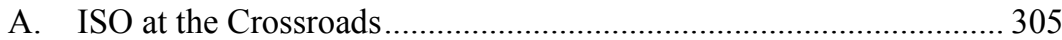

B. Reviewing ISO Practices Against the Principles of the TBT

Committee Decision...................................................................... 311

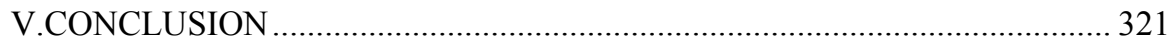

\section{INTRODUCTION}

International standards play an increasingly conspicuous role in WTO agreements. ${ }^{1}$ It is telling that the preamble of the Agreement on Technical Barriers to Trade (TBT), one of the WTO-covered agreements, ${ }^{2}$ commences with the assumption that international standards improve efficiency of production and facilitate the conduct of international trade. ${ }^{3}$ Therefore, they should be adhered to for all practical purposes. The Agreement on Sanitary and Phytosanitary Measures (SPS) includes statements along similar lines. ${ }^{4}$

1. WTO Agreement: Marrakesh Agreement Establishing the World Trade Organization, Apr. 15, 1994, 1867 U.N.T.S. 154, at 9 [hereinafter Marrakesh Agreement or WTO Agreement].

2. Agreement on Technical Barriers to Trade, annex 1A WTO Agreement, Apr. 15, 1994, 1868 U.N.T.S. 120, at 5 [hereinafter TBT].

3. Id.; see also Peter Swann et al., Standards and Trade Performance: the UK Experience, 106 ECON. J. 1297, 1297-313 (1996).

4. See Agreement on the Application of Sanitary and Phytosanitary Measures, annex 1A WTO Agreement, Ap. 15, 1994, 1867 U.N.T.S. 493, at 71-83 [hereinafter SPS]. 
Standards are a form of codified technical knowledge that enables the development of products and processes. While voluntary, standards regularize and constrain behavior (regulative function), lend a taken-forgranted quality to certain technologies and modi operandi (cognitive function), and favor cooperative strategies over adversarial ones (normative function). ${ }^{5}$ The last function in particular can have a long-lasting beneficial effect because standardization creates an infrastructure that, once created, gives parties an incentive to use it, resulting in increased cooperation and enabling users to take full advantage of the network effects of standardization. ${ }^{6}$ In addition, first mover advantages in standardization ${ }^{7}$ are substantial incentives for firms to innovate. ${ }^{8}$ Absent some form of standardsetting, technological progress would miss an important instrument for benchmarking and capitalizing on advances in the field of technology. In that sense, standards are constitutive of markets $^{9}$ and a decisive instrument for economic growth. ${ }^{10}$

On the other hand, standards can also impede trade. This is because they reflect preferences and values of a given populace that may - and often dodiverge, thereby inflating compliance costs for companies. ${ }^{11}$ If developed internationally, substantial gains can be made through the diminution of such costs and by addressing network externalities and information asymmetries. ${ }^{12}$ As a result, international standardization has become the preferred layer of regulatory action, both government and private driven. ${ }^{13}$

5. Christel Lane, The Social Regulation of Inter-Firm Relations in Britain and Germany: Market Rules, Legal Norms and Technical Standards, 21 CAMBRIDGE J. ECON. 197, 197 (1997).

6. Michael L. Katz \& Carl Shapiro, Systems Competition and Network Effects, 8 J. ECON. PERSP. 93, 109 (1994).

7. Art. 1.1 of the ISO/IEC Guide 2: 2004 [hereinafter The Guide] defines standardization as the "activity of establishing, with regard to actual or potential problems, provisions for common and repeated use, aimed at the achievement of the optimum degree of order in a given context. Note 1: in particular, the activity consists of the processes of formulating, issuing, and implementing standards."

8. Again, and more generally, if we consider standardization as infrastructure, it can promote but also hamper innovation. See also Daron Acemoglu et al., Competing Engines of Growth: Innovation and Standardization, 147 J. ECON. THEORY 570, 573 (2012).

9. Harm Schepel, The CONSTITUTION OF PRIVATE GOVERnANCE - ProduCt STANDARdS IN THE REGULATION OF INTEGRATING MARKETS (2005).

10. Knut Blind \& Andre Jungmittag, The Impact of Patents and Standards on Macroeconomic Growth: A Panel Approach Covering Four Countries and 12 Sectors, 29 J. ProduCtivity ANALYSIS 51, 51 (2008).

11. Robert W. Staiger \& Alan O. Sykes, International Trade, National Treatment and Domestic Regulation, 40 J. LEGAL STUD. 149, 152 (2011).

12. See WTO, World TRAde RePORT 2005 at xxvi-xvii (2005).

13. Walter Mattli \& Tim Büthe, Setting International Standards - Technological Rationality or Primacy of Power?, 56 World POL. 1, 7 (2003); Kristina Tamm Hallström, ORGANIZING INTERNATIONAL STANDARDIZATION - ISO AND THE IASC IN QUEST OF AUTHORITY (2004). 
Globalization vindicates this choice; as the importance of global supply chains increases, international standards grow equally in prominence. ${ }^{14}$

The cost of this seemingly irreversible shift of locus of standardization depends on the level of sophistication of the relevant firms. The consumer, on the other hand, is a net winner due to this development; economic theory would suggest that an international standard reduces consumer costs as information becomes more readily available and prices become more readily comparable. ${ }^{15}$

The WTO, generally reluctant to use non-WTO material to assess the WTO compliance of a given Member, ${ }^{16}$ is more lenient when the output of international standard-setting bodies (ISSBs) is at stake. Much of previous WTO case law ${ }^{17}$ exemplifies this deferential approach. In both cases, nonconsensual international standards were considered relevant benchmarks for assessing WTO compatibility of national measures. This is quite extraordinary for a consensus-driven organization like the WTO, whereby the legacy of consensus is a major hallmark of the multilateral trading system.

The texts of the SPS and TBT, respectively, only partially vindicate such unconditional deference to ISSBs. More recently, in US-Tuna II, the Appellate Body has given signs of a more critical approach vis-à-vis nonWTO standards as relevant benchmarks for assessing compliance with WTO law. ${ }^{18}$ The Appellate Body ruled that no automatic and thus mechanical comparison should be made between the relevant international standard and the measure at issue in a WTO dispute. Rather, before this comparison takes place, an examination of the procedural and substantive guarantees of the standard-setter at issue is opportune if its output is to play a decisive role in finding a violation of WTO law.

14. World Economic Forum (WEF), The Global EnABling Trade REPORT 2012 - Reducing SUPPLY CHAIN BARRIERS (2012).

15. See WTO, World Trade Report 2012, 136 (2012).

16. See Panagiotis Delimatsis, The Fragmentation of International Trade Law, 45 J. WORLD TRADE 87,102-03 (2011).

17. See generally Appellate Body Report, European Communities - Measures Concerning Meat and Meat Products, WTO Doc. WT/DS26/AB/R \& WTO Doc. WT/DS48/AB/R (Jan. 16, 1998) [hereinafter EC - Hormones]; Appellate Body Report, European Communities - Trade Description of Sardines, WT/DS231/AB/R (Sep. 26, 2002) [hereinafter EC - Sardines]. Nowadays, mention is exclusively made of the European Union and no longer of the European Community, as a result of the entry of the Treaty of Lisbon into force. See Consolidated Version of the Treaty on the European Union, art. 1(3), 7 June 2016 [hereinafter TEU].

18. See Appellate Body Report, United States - Measures Concerning the Importation, Marketing and Sale of Tuna and Tuna Products, WTO Doc. WT/DS381/AB/R (June 13, 2012) [hereinafter US Tuna II]. 
This judicial finding points to the penumbra of processes used within ISSBs. Admittedly, our knowledge about the mechanics of international standard-setting is quite limited. Hearsay about lack of representation and inclusiveness is not uncommon, whereas anecdotal evidence about power politics and strategic behavior makes headlines from time to time. More recently, the shortcomings of international standardization processes became a central issue in the non-agricultural market access (NAMA) negotiations within the WTO. ${ }^{19}$

Against this backdrop, a closer analysis of the properties of international standard-setting is apposite and timely. Recognition of any rule presupposes contestation, which, in turn, inevitably inquires into how standards are adopted. ${ }^{20}$ Taking as an example the International Organization for Standardization (ISO), the most important standard-setting body globally, this article analyzes the procedural and substantive guarantees regarding transparency, openness, deliberation, and participation within international standard-setting processes. This exercise aims to identify the processes that ensure that international standards adopted in these fora are in line with basic tenets of due process.

A central argument of this article is that attributing automatic legal force in the WTO to international standards developed elsewhere is untenable. Such an approach is contrary to contemporary demands for more transparency and due process within global governance institutions generally, and openness in international standard-setting in particular. ${ }^{21}$ More importantly, we deploy the analysis on ISO to submit that, in times of increased legalization of international rule-making at the transnational level, an examination of the necessary guarantees (or a "democratic minimum") ${ }^{22}$ with which an international standard-setter would need to comply is indispensable.

At this juncture, the role and influence of the WTO as a potential driver for a new approach in international standard-setting, or "standard-setting

19. See WTO, Negotiating Group on Market Access, 'Market Access for Non-Agricultural Products - International Standards in Support of Trade and Economic Development: Strengthening the Contribution of the Committee Decision', WTO Doc. TN/MA/W/141 (March 29, 2011) (referring to the TBT Committee Decision relating to the development of international standards, see infra, Section II).

20. See Harm Schepel, Rules of Recognition: A Legal Constructivist Approach to Transnational Private Regulation, in REGULATORY HYBRIDIZATION IN THE TRANSNATIONAL SPHERE 189, 197 (Paulius Jurčys et al. eds., 2013).

21. See Armin von Bogdandy, The European Lesson for International Democracy: The Significance of Articles 9-12 EU Treaty for International Organizations, 23 EUR. J. INT'L L. 315, 331 (2012).

22. See Nico Krisch, The Decay of Consent: International Law in an Age of Global Public Goods, 108 AM. J. INT’L L. 1, 16 (2014). 
2.0," will also form part of the analysis that the article offers. Section II describes the position of international standards in the TBT by reference to the current legal framework and case law, while Section III presents an account of ISO standard-setting processes. A critical assessment of standardsetting practices within ISO follows in Section IV.

\section{INTERNATIONAL STANDARDS AND THE TBT}

The multilateral trading system was initially based on a negative integration contractual approach; non-discrimination has been the overarching principle of the system and the linchpin of this approach, allowing sufficient leeway for domestic regulatory authorities to unilaterally define the set of policies they would want to adopt. Thus, international standards and, a fortiori, the bodies that promulgate them were outside the reach of the General Agreement on Tariffs and Trade (GATT), which meant that the international standardization regime and the multilateral trading regime would pave their own, distinct ways of exerting influence over commercial transactions. ${ }^{23}$

The advent of the WTO would not change much with respect to the lack of any capacity of the trading system to create technical standards itself. However, the level of integration sought regarding non-tariff barriers would change, with greater emphasis on regulations of technical nature and measures purportedly taken to protect public health or safety. ${ }^{24}$ Both the TBT and the SPS would now clearly strive for regulatory convergence using international standards as benchmarks regarding the direction such convergence should take. ${ }^{25}$ Standards created in ISSBs, such as ISO, the International Electrotechnical Commission (IEC), or the Codex Alimentarius, were invariably regarded as authoritative expressions of international technical consensus. They could be used as proxies that would allow for properly striking the balance in any given case between protectionist-driven domestic regulations and the well-meant protection of non-economic, public policy objectives. Thus, non-WTO material-i.e.,

23. It is only in the Tokyo Round in the mid-70s that the issue of technical barriers to trade and the role that international standards could play was discussed, leading to a plurilateral agreement. See ALAN O. SYKES, PRODUCT STANDARDS FOR INTERNATIONALLY INTEGRATED GOODS MARKETS, 57-77 (1995).

24. See Jacqueline Peel, A GMO by Any Other Name ... Might Be an SPS Risk!: Implications of Expanding the Scope of the WTO Sanitary and Phytosanitary Measures Agreement, 17 EUR. J. INT'L L. 1008, 1013 (2007).

25. See Gabrielle Marceau \& Joel P. Trachtman, The Technical Barriers to Trade Agreement, The Sanitary and Phytosanitary Measures Agreement, and The General Agreement on Tariffs and Trade: A Map of the World Trade Organization Law of Domestic Regulation of Goods, 36 J. WorLD TRADE 811, 886-93 (2002). 
international standards - would play the role of useful heuristic devices in this new area of growing positive integration within the WTO. The absence of a standard-setting capacity by the TBT and SPS committees, or the WTO more generally, warranted the introduction of non-WTO material by reference.

\section{A. Technical Regulations and (International) Standards under the TBT}

The TBT distinguishes between two types of measures: technical regulations and standards. ${ }^{26}$ The difference between the two lies in the degree of compliance: whereas compliance is mandatory for technical regulations, it is only voluntary in the case of standards. Still, some overlap regarding the scope of the two categories is evident by reading the definitions in the TBT Agreement; they both cover labeling requirements and production and process methods (PPMs). An additional difference between technical regulations and standards relates to the source of the measure: whereas technical regulations would typically be adopted by a governmental body and thus be a State measure, standards are typically issued by private or semiprivate SSBs. Standards can later become technical regulations (or part thereof) if adopted or used as a basis for legislative acts by the State.

In practice, the distinction between the two is not always straightforward and can confuse regulators, companies, and courts alike. Recently, in US-Tuna II, the WTO adjudicating bodies blurred the distinction between the two types of TBT measures by arguing that a voluntary dolphin-safe labeling scheme for tuna products access (which is subject to certain criteria as to how the tuna was harvested) is a technical regulation and not a standard, although access to the US market for tuna was available. $^{27}$

Article 2.4 of the TBT is the key provision when examining the relation between international standards and the TBT. Pursuant to this provision, relevant international standards or relevant parts thereof (when they exist or are about to be adopted) must be used as a basis for domestic technical regulations unless they are ineffective means for meeting the public policy objectives. International standards are used as a basis when they are the

26. TBT, supra note 2, at annex 1. On the definition of technical regulation in annex 1.1 , see Appellate Body Report, European Communities - Measures Prohibiting the Importation and Marketing of Seal Products, WTO Doc. WT/DS400/AB/R \& WTO Doc. WT/DS401/AB/R (May 22, 2014), ๆ 5.8ff [hereinafter $E C-$ Seal Products].

27. See also Panagiotis Delimatsis, "Relevant International Standards" and "Recognized Standardisation Bodies" under the TBT Agreement, in THE LAW, ECONOMICS AND POLITICS OF INTERNATIONAL STANDARDISATION 104, 119 (Panagiotis Delimatsis ed., 2015). 
principal constituent or fundamental principle for the purpose of enacting the technical regulation at stake. Furthermore, there is no restriction with respect to time. Hence, international standards created before the entry of the TBT into force can also be relevant if the state of the art has not changed in the meantime with the adoption of a new international standard. ${ }^{28}$ In other words, previously voluntary standards suddenly become mandatory benchmarks for domestic technical regulations. ${ }^{29}$

Article 2.5 incorporates a presumption of TBT compatibility for those technical regulations that are in accordance with relevant international standards and pursue a legitimate objective. The rationale behind this "safe haven" is that voluntary international standards incorporate international preferences and constitute artifacts of widely accepted technical superiority. In addition, Article 2.9 imposes additional notification requirements in case relevant international standards are not used.

Hence, the tilt toward the use of relevant international standards manifests in a variety of ways: first, a requirement that members use relevant international standards in a positive manner and the creation of a rebuttable presumption of consistency as an extra "carrot"; second, the imposition of additional burdensome conditions that members need to abide by if they disregard or decide not to use international standards.

As a consequence of TBT's unequivocal preference, then, in those areas where international standards exist, they become the reference point and de facto mandatory normative technical material to be used by WTO Members. As a result, a mass of documents of at best uncertain legal normativity is transformed into international obligations equivalent to treaty text. ${ }^{30}$ As noted earlier, this is even more striking if one considers the meticulous character of the analysis that the WTO adjudicating bodies typically undertake when attempting to classify particular legal texts under one of the subparagraphs of Article 31 of the Vienna Convention on the Law of Treaties (VCLT).

For such an unambiguous endorsement of legal material generated outside the WTO, the TBT Agreement is quite cryptic with respect to what

28. EC-Sardines, $\uparrow 205$.

29. This changed forever the way international standards, particularly those created within ISO, were perceived by States; ISSBs grew in salience, but also came under States' and scholars' spotlights, very quickly. See Winton Higgins \& Kristina Tamm Hallström, Standardization, Globalization and Rationalities of Government, 14 ORGANIZATION 685, 696 (2007).

30. See Robert Howse, A New Device for Creating International Legal Normativity: The WTO Technical Barriers to Trade Agreement and "International Standards", in CONSTITUTIONALISM, MultileVEl Trade GOVERnANCE AND InTERnATIONAL ECONOMIC LAW 383, 384 (Christian Joerges \& Ernst-Ulrich Petersmann eds., 2011). 
constitutes a relevant international standard. ${ }^{31}$ Only a generic definition of "standard" is available in the TBT:

Document approved by a recognized body, that provides, for common and repeated use, rules, guidelines or characteristics for products or related processes and production methods, with which compliance is not mandatory. It may also include or deal exclusively with terminology, symbols, packaging, marking or labelling requirements as they apply to a product, process or production method. ${ }^{32}$

Importantly, the explanatory note that follows suggests that, whereas standards adopted by the "international standardization community" are based on consensus, the TBT also covers documents that are not based on consensus. $^{33}$

The definition of a standard in the ISO/IEC Guide 2:2004 is, ${ }^{34}$ for all practical purposes, similar to the one in the TBT, albeit with important nuances:

[D]ocument, established by consensus and approved by a recognized body, that provides for common and repeated use, rules, guidelines or characteristics for activities or their results, aimed at the achievement of the optimum degree of order in a given context. Note: Standards should be based on the consolidated results of science, technology and experience, and aimed at the promotion of optimum community benefits. ${ }^{35}$

As one can infer, a crucial difference between the two definitions provided above is the role of consensus when considering whether a particular technical content could be deemed a standard.

\section{B. Standardizing Organizations and "Recognized" Bodies}

The Guide further considers as international those standards that are adopted by an international standardizing/standards organization and made

31. The lack of a definition of what an international standard is may also be due to the fundamental disagreement between the EU and the US as to what an international standard and an international standard-setting body stand for. This same question lies at the heart of the negotiations for a Transatlantic Trade and Investment Partnership (TTIP). See CEN/CENELEC Position Paper on EU-US Transatlantic Trade and Investment Partnership (TTIP) - Technical Barriers to Trade, Initial EU Position Paper (Sept. 2013).

32. TBT, supra note 2, at 132 (emphasis added).

33. Id. ("For the purpose of this Agreement standards are defined as voluntary and technical regulations as mandatory documents. Standards prepared by the international standardization community are based on consensus. This Agreement covers also documents that are not based on consensus.”)

34. The Guide is an update of ISO/IEC Guide 2:1991 on which the TBT is based. See note 7.

35. See The Guide, supra note 7, at 38 (emphasis added). 
available to the public. ${ }^{36}$ In turn, an international standardizing organization is defined in the Guide as "the organization" (that is, the body that is based in the membership of other bodies or individuals and has an "established constitution and its own administration") whose membership is open to the relevant national body from every country. ${ }^{37}$ The TBT defines international bodies in an open-ended manner: international body is the body or system whose membership is open to the relevant bodies of all WTO Members. In other words, when examining the international nature of a standard, attention should center on the traits of the institution promulgating $\mathrm{it}^{38}$ rather than the very content of the standard at issue. ${ }^{39}$

Regarding the traits that such an institution should have, the TBT definition of standards refers to "recognized" standardization bodies. By the same token, Article 4.3 of the ISO/IEC Guide 2:2004 defines as standardizing those bodies which have recognized activities in standardization. ${ }^{40}$ On the other hand, the TBT references a recognized standardization body. In US - Tuna II, the Appellate Body suggested that recognition is reserved for active standardization bodies and suggested that "the larger the number of countries that participate in the development of a standard, the more likely it can be said that the respective body's activities in standardization are 'recognized'.,41

Thus, recognition within the meaning of Article 1.2 of the TBT would be a function of the degree of recognition by WTO Members (through participation), rather than the standardization community. The Appellate Body also noted that no quantitative benchmark should be in place with respect to standardization activities. It appears that, in this case, contextual analysis would be necessary to find that a given body has recognized activities on international standardization. For instance, evidence with respect to (a) the level of participation of WTO Members in the development of a given standard; (b) wide recognition of the validity and legality of even

36. Echoed in Regulation 1025/2012 of the European Parliament and of the Council of 25 Oct. 2012, on European Standardisation, art. 2(1)(a), 2012 O.J. (L 316/12) 19 [hereinafter EU Regulation $1025 / 2012]$.

37. See The Guide, supra note 7, at 39-41.

38. Compare the distinction between international, European, and national standards in the EU Regulation 1025/2012, supra note 36, at art. 2(1)(a), (b) and (d).

39. See also Communication from Columbia, Committee on Technical Barriers to Trade, Sixth Triennial Review of the Agreement on Technical Barriers to Trade: Standards, 18 ff, WTO Doc. G/TBT/W/351 (Mar. 21, 2012)

40. In US - Tuna II, the Appellate Body found that the ISO definition of a standardizing body should assist in the interpretation of the TBT term 'recognized body'. See US - Tuna II, supra note 18, at $₫ 362$.

41. US - Tuna II, supra note 18 , at $₫ 390$. 
a single standard; and (c) adherence to the TBT Committee Decision of 2000 on principles for the development of international standards (the "TBT Committee Decision") would influence the decision as to whether certain standardization activities are "recognized."

For the first time in US-Tuna II, in a highly important jurisprudential turn, adherence to the TBT Committee Decision was linked to the issue of whether a given standard-setting body has recognized activities. In previous WTO disputes, international standards that were adopted with limited majority were considered as relevant international standards by the WTO adjudicating bodies for the purposes of Article 2.4 of the TBT. In $E C-$ Sardines, the relevant Codex Alimentarius standard was adopted by 18 parties out of over 150 at that time. ${ }^{42}$ Similarly, in EC-Hormones, the GMO standard (an SPS standard, but still indicative of the trend within the WTO vis-à-vis international standards) was adopted with 33 votes against 29 and 7 abstentions. Both standards were adopted before 1995, that is, in a period where the GATT did not use international standards as benchmarks for GATT consistency. ${ }^{43}$ Therefore, the interest for participating in the creation of essentially voluntary technical specifications at the international level was reduced.

However, in the aftermath of the multilateral adoption of the TBT and SPS in 1995, higher levels of scrutiny of standard-setting practices were deemed to be warranted, and these disputes only served to alert WTO Members as to the possible challenges that an unqualified endorsement of standards adopted elsewhere would entail. Indeed, such jurisprudence, which in practice failed to take into account important controversies and debates in ISSBs, was sitting uncomfortably with the advocacy for more openness and better governance in global institutions. ${ }^{44}$

As a result, in the year 2000, the TBT Committee agreed on six principles that should be observed by ISSBs when they develop international standards: transparency; openness; impartiality and consensus; effectiveness

42. Panel Report, European Communities-Trade Description of Sardines, ฯ 5, WTO Doc. WT/DS231/R (May 29, 2002) [hereinafter EC - Sardines].

43. It should be noted here that the multilateral Tokyo Round Code on Technical Barriers to Trade (the 'Standards Code'), included in its art. 2.2 a provision similar to art. 2.4 TBT. However, the Code was only binding to those GATT contracting parties subscribing to it, that is, 32 countries at the time.

44. Having said this, this jurisprudence is perhaps indicative of the WTO's reluctance to engage in a discussion as to the legality of standards developed within Codex Alimentarius. Controversy is still present as to the standard-setting practices of the Codex as exemplified by the recent Ractopamine case. See Alessandra Arcuri, The Coproduction of the Global Regulatory Regime for Food Safety Standards: the SPS, Codex and the Limits of Technocratic Ethos, in THE LAW, ECONOMICS AND POLITICS OF INTERNATIONAL STANDARDISATION 79 (Panagiotis Delimatsis ed., 2015). 
and relevance; coherence; and addressing the concerns of the developing world (the so-called "development dimension"). This was a consensusdriven signal by the WTO that rules and procedures in ISSBs had to be strengthened. Clearly, it was an external call for reform of international standard-setting activities. ${ }^{45}$

\section{Upgrading the TBT Committee Decision}

Although the WTO adjudicating bodies rejected the EU's position in $E C$-Sardines and EC-Hormones regarding the relevance of the international standards at issue for assessing TBT compliance, anecdotal evidence suggests that much of the TBT Committee Decision of 2000 was driven by the U.S., which came to realize that the EU was unduly dominating the domain of international standardization. ${ }^{46}$ The legal value of the Decision quickly became a controversial topic. In $E C$-Sardines, the Panel found that the Decision was not binding, but a mere "policy statement of preference." Thus, the fact that the Codex standard at issue was not adopted by consensus was immaterial. However, the TBT Committee Decision had a substantial impact on standard-setting processes, particularly within ISO. Whereas ISO very early reacted positively to the TBT Committee Decision and alleged that it complied with the principles enshrined therein, ${ }^{48}$ it also intensified its work with respect to ensuring due process in standards development, accommodating more intensively the concerns of developing countries or broadening the circle of stakeholder participation.

The Appellate Body was not called upon to review the Panel's finding in EC-Sardines, but was given the opportunity to address the issue ten years later in US-Tuna II. Disagreeing with the Panel in EC-Sardines, the Appellate Body considered the TBT Committee Decision as a "subsequent agreement" within the meaning of Article 31(3)(a) VCLT, which obliges any WTO treaty interpreter to read the Decision together with the text of the TBT. The Appellate Body was led to this conclusion based on various elements. The Decision was adopted by consensus; it bears specifically upon the interpretation and application of a TBT provision and constitutes a

45. See WTO, TBT Committee, "Second Triennial Review of the Operation and Implementation of the Agreement on Technical Barriers to Trade, annex 4: Decision of the Committee on Principles for the Development of International Standards, Guides and Recommendations with Relation to art. 2, 5 and annex 3 of the Agreement," G/TBT/9, Nov. 13, 2000.

46. I would like to thank Amelia Porges for pointing out this part of the negotiating history to me.

47. EC-Sardines, $₫ 7.91$.

48. See WTO, TBT Committee, "Developments within the International Organization for Standardization (ISO) that are related to the Second Triennial Review of the TBT Agreement," Communication from ISO, G/TBT/W/158 (May 18, 2001). 
testimony of Members' expressed intention to: (a) develop a better understanding of international standards; (b) ensure the effective application of the TBT; and (c) clarify and strengthen the concept of international standards. $^{49}$

Indeed, agreements following the conclusion of a previous agreement aiming to specify how existing rules or obligations are to be applied (rather than to create new - or extend existing - obligations) can fall under Article 31(3)(a) VCLT, constituting a further authentic element of interpretation to be taken into account along with context. ${ }^{50}$ However, considering the TBT Committee Decision as a "subsequent agreement" barely squares with the $E C$-Sardines previous finding that the last sentence of the Explanatory Note in Annex 1.2 TBT also relates to international standards. Then, if no consensus is required for a standard to be regarded as a "relevant international standard," the TBT Committee Decision, by requiring consensus, amounts to an amendment of the TBT text, at least as far as international standards are concerned. ${ }^{51}$ Nonetheless, the Appellate Body failed to reach such a conclusion expressly.

Still, based on these considerations, the Appellate Body found that an invitation-only regional standard-setting body (such as the Agreement on the International Dolphin Conservation Program-AIDCP, the relevant standard invoked by Mexico) is not open to all WTO Members. ${ }^{52}$ It also noted that, in more generalized terms, standardization bodies must be open and transparent at every stage of developing standards in line with the TBT Committee Decision.

\section{Interim Conclusion}

In sum, the TBT exerts a high level of deference towards technical rationality as expressed through international standard-setting activities outside the WTO. Standards developed within ISSBs acquire a prominent role at the WTO through the very text of Articles 2.4 and 2.5 of the TBT, which requires that WTO Members use "relevant international standards" and presume compliance with the TBT when such standards are used as a basis for domestic technical regulations. It is one thing to state that the TBT

49. US - Tuna II, supra note 18, at $9 \uparrow \mid 371-2$.

50. See Appellate Body Report, EC - Bananas III (art. 21.5 - Ecuador II), $\{391$; and Appellate Body Report, US - Clove Cigarettes, $\uparrow 265$.

51. Practice in preferential trade agreements (PTAs) would also suggest that Members by now view the TBT Committee Decision as the authoritative document for identifying what an international standard is. See, among many others, the US-Australia Free Trade Agreement, Chapter 8 (TBT), art. 8.4.2.

52. However, the Appellate Body cautioned that such a body could still be considered as open if the invitation was a mere formality. See US - Tuna II, supra note 18 , at $\uparrow 386$. 
Committee would be unable to develop any standards whatsoever. It is quite another to claim that certain non-WTO rules can vindicate WTO consistency as long as they are relevant to the product at issue in a WTO dispute regardless of the process that led to their adoption. ${ }^{53}$

Quite astonishingly, the TBT entails such delegation of regulatory power $^{54}$ without any inquiry into the actual processes used throughout the development of international technical standards. This is even more surprising if one considers that such regulatory outsourcing is directed towards private actors, thereby creating an alternative to formal international law. ${ }^{55}$ The US-Tuna II case appears to set the foundations for a shift towards a more critical approach that would take into account procedural and substantive safeguards within ISSBs when they develop and approve international standards.

This only makes sense: ISO in its capacity as the largest purveyor of international standards inevitably draws normativity and authority from the users of its standards, that is, traders originating in WTO Members. In other words, the WTO is the ex post "legitimizer" of international standards by default as per Article 2.4 of the TBT, but it can potentially be an ex post arbiter of their legitimacy or a third-level authoritative monitoring and enforcement device for international standardization in general.

For these reasons, surveying with a view to identifying such guarantees is important. In the next Section, we discuss the existing procedural and substantive guarantees in the ISO.

\section{PROCEDURAL AND SUBSTANTIVE SAFEGUARDS IN ISO}

For many decades, standardization has served a complementary function to traditional (domestic) command-and-control regulation. ${ }^{56}$ Indeed, theory suggests that non-binding, or "soft," norms such as standards serve a gap-filling function for "harder" forms of law. ${ }^{57}$ Modern States concede part of their powers to other actors which can act more effectively

53. Recall that this process is totally out of the control of the WTO.

54. For a similar observation under the SPS, see, Tim Büthe, The globalization of health and safety standards: delegation of regulatory authority in the SPS Agreement of 1994 establishing the World Trade Organization, 71 LAW \& CONTEMP. PROBS. 219, 220 (2008).

55. Eyal Benvenisti, "Coalitions of the Willing” and the Evolution of Informal International Law, in COAlitions of THE Willing: Avantgarde OR Threat? 1 (Christian Calliess et al. eds., 2007).

56. As Schepel puts it, "regulators count on [private standards], markets cannot function without them." See Harm Schepel, Constituting Private Governance Regimes: Standards Bodies in American Law, in TRANSNATIONAL GOVERNANCE AND CONSTITUTIONALISM 161, 164 (Christian Joerges et al. eds., 2004).

57. Linda SENDEN, SOFT LAW IN EUROPEAN COMMUNITY LAW 119-120 (2004). 
and swiftly mainly due to their expertise, focus, and smaller size. This allows non-state voices to be heard, whereas States reshuffle their regulatory behavior and supervisory role (for instance, by focusing on ex post control of a certain activity). ${ }^{58}$ The advantages of non-coercive, "soft" forms of regulation transform States into catalysts, coordinators, and supporters of certain activities at the national or transnational level. ${ }^{59}$ Notably, the development of global business leads to an unprecedented expansion of regulatory rules that have a variety of penholders that are typically closer to the regulated object. ${ }^{60}$

Standardization is a quasi-legal form of self-regulation and, depending on the circumstances and the legal context at hand, it can be a form of coregulation, or else a (hybrid) public-private partnership. ${ }^{61}$ Some regional standardization bodies like the European Committee for Standardization (CEN) fall under the latter category. ${ }^{62}$ With regard to the EU in particular, it is by now generally accepted that much of the influence that the EU member States exercise within the ISSBs is attributed to the New Approach, first introduced in the mid-80s. ${ }^{63}$ This approach towards standardization created a sophisticated cooperative network on standards development at the EU level among national SSBs, the European Commission, companies, and the European SSBs. It also aligned the functioning of European standard-setters with ISSBs through the creation of mirror committees. This network essentially delegated the creation of all technology-related content to the European SSBs. The New Approach revolutionized the way trade was conducted at the EU level and beyond, but also the way that standard-setting at the EU level (CEN, CENELEC, ETSI) mirrored standard-setting at the international level (ISO, IEC, ITU). ${ }^{64}$

58. JOHN H. JACKSON, SOVEREIGNTY, THE WTO AND CHANGING FUNDAMENTALS OF INTERNATIONAL LAW 57-62 (2006); see also HENDRIK SPRUYT, THE SOVEREIGN STATE AND ITS COMPETITORS 20-21 (1994).

59. Kenneth W. ABbott \& DunCAn Snidal, The Governance Triangle: Regulatory Standards Institutions and the Shadow of the State, in THe Politics of Global REGUlAtion 57-59 (Walter Mattli \& Ngaire Woods eds., 2009).

60. See David Levi-Faur, The Global Diffusion of Regulatory Capitalism, 598 ANNALS AM. ACAD. POL. \& SOC. SCI. 12, 13 (2005).

61. See NILS BRUNSSON, Organizations, Markets and Standardization, in A WORLD OF STANDARDS 27-28 (Nils Brunsson \& Bengt Jacobsson eds., 2000).

62. The Regulatory Function of European Private Law 37 (Fabrizio Cafaggi \& Horatia Muir Watt Elgar eds., 2009).

63. Panagiotis Delimatsis, Standardization in Services - European Ambitions and Sectoral Realities, 4 EUR. L. REV. 513, 522 (2016).

64. See SCHEPEL, supra note 9, at 104-107; see also European Commission Communication, A strategic vision for European standards: Moving forward to enhance and accelerate the sustainable growth of the European economy by 2020, at 17-19, COM (2011) 311 final (June 1, 2011). 
This approach is consistent with the premises of technical rationality, ${ }^{65}$ a kind of technocratic legitimacy or technocracy-based subsidiarity. It is considered as the result of low sovereignty costs for governments, all the more because standardization activities typically result in output of voluntary nature. ${ }^{66}$ Even so, it is indicative of the ever-increasing expansion of legitimate authority outside the State. ${ }^{67}$ However, under certain circumstances it may be worrisome if this type of soft law preempts hard forms of law, which may be justifiably more intrusive, seeking higher levels of protection. ${ }^{68}$

As there are manifold technological approaches, an SSB offers a forum where competitors and competing vested interests can resolve conflicts and coordination problems. ${ }^{69}$ Due to its importance, substantial financial resources and efforts are invested in standardization fora. ${ }^{70}$ The increase of standards-related patent disputes and the emergence of industry-sponsored consortia (but also actions against anticompetitive practices) are indicative of the growing importance of standardization particularly in high-tech areas. $^{71}$ In this regard, for innovation to occur, an active, resourceful participation in standardization activities is necessary.

Notwithstanding the importance of technical rationality and technical strength in standardization activities, standardization can become a highly

65. Luis M. B. CABral \& TOBIAS KRETSChmer, Standards battles and public policy, in StandardS AND PUBlic POLICY 329-31 (Shane Greenstein \& Victor Stango eds., 2007); Thomas A. Loya \& John Boli, Standarization in the World Polity: Technical Rationality over Power, in CONSTRUCTING WORLD CUltuRE: INTERNATIONAL NONGOVERNMENTAL ORGANIZATIONS SINCE 1875 169-171 (John Boli \& George M. Thomas eds., 1999).

66. See Kenneth W. Abbott \& Duncan Snidal, Hard and Soft Law in International Governance, 54 INT'L ORGANIZATION 421, 441 (2000).

67. See generally David J. Vogel, Private Global Business Regulation, 11 ANN. REV. PoL. SCI. 261, 261 (2008).

68. See NaOmi Roht-ArriazA, "Soft Law" in a "Hybrid" Organization: The International Organization for Standardization, in COMMITMENT AND COMPLIANCE - THE ROLE OF NON-BINDING Norms In THE InTERNATIONAL LEGAL SySTEM 263, 272-273 (Dinah Shelton ed., 2000).

69. See Josh Lerner \& Jean Tirole, Standard-Essential Patents, 123 J. POL. ECON. 547, 547-48 (2015) (arguing that SSBs perform three functions: a discovery, standardization and a regulatory function).

70. See Joseph Farrell \& Timothy Simcoe, Choosing the Rules for Consensus Standardization, 43 RAND J. ECON. 235, 236-38 (2012). See also the observation of the Advocate-General Campos SanchezBordona in the recent Elliott case before the CJEU that '[i]ndustry assumes the greater share of the costs of standardization. . . Case C-613/14, James Elliott Construction Limited v. Irish Asphalt Limited, ECLI:EU:C:2016:63 (2016), $₫ 58$.

71. See Mark Lemley, Ten Things to Do About Patent Holdup of Standards (and One Not to), 48 B.C. L. REV. 149, 154 (2007); see also Pierre Larouche \& Geertrui Van Overwalle, Interoperability standards, patents and competition policy, in THE LAW, ECONOMICS AND POLITICS OF INTERNATIONAL STANDARDisATION 79 (Panagiotis Delimatsis ed., 2015). 
politicized process whereby economic interests along with the quest for dominance among state and non-state actors shape its functioning. ${ }^{72}$ The more important the stakes in standardization become, the fiercer the competition for increased influence in SSBs is. ${ }^{73}$ Evidence suggests that power politics and regulatory capture by the big States may be endemic to international standard-setting. ${ }^{74}$

Standardization can also be captured by the industries involved, which exploit the presence of asymmetric information and organization. ${ }^{75}$ An additional variable in this respect is the perennial conflict of interest that is endemic in SSBs because those subject to the standards are also those that promulgate them. Industries organize themselves more efficiently than consumers and manage to capture standard-setting institutions. This can also be the result of structural bias: ${ }^{76}$ for instance, ISO is a mainly nongovernmental, industry-driven, international standard-setter.

More recently established sustainability-centered SSBs such as the International Social and Environmental Accreditation and Labelling (ISEAL) Alliance claim to be more inclusive. ${ }^{77}$ Yet, even in such bodies, full membership is reserved to those presumed to have the necessary technical expertise; that is, standard-setting organizations and accreditation bodies. ${ }^{78}$ Consumer associations or NGOs are barely involved in the actual development of the standards, but may engage more at a later stage in the consultation process and shortly before the standard becomes final. The stakeholders involved in international standardization are of a hybrid nature

72. See Jo Swinnen \& Thijs Vandemoortele, Trade and the Political Economy of Standards, 11 World Trade ReV. 390, 391 (2012); Pablo Marquez, Standardization and Capture: The Rise of Standardization in International Industrial Regulation and Global Administrative Law, 7 GLOBAL JURIST 1, 2 (2007).

73. See Stanley M. Besen \& Joseph Farrell, Choosing How to Compete: Strategies and Tactics in Standardization, 8 J. ECON. PERSP. 117, 121 (1994).

74. Daniel W. Drezner, All Politics is Global: Explaining International Regulatory REgIMES (2007); JOHN BRAithWAite \& PÉTER DRAHos, Global Business REGUlation (2000).

75. In the case of accounting standards, see S.P. Kothari; Karthik Ramann \& Douglas J. Skinner, Implications for GAAP from an analysis of positive research in accounting, $20 \mathrm{~J}$. ACCT. ECON. 246, 251 (2010).

76. See Martti Koskenniemi, The Politics of International Law - 20 Years Later, 20 EUR. J. INT'L L. 7, 9 (2009).

77. ISO considers all these relatively new standard-setters as developing purely "private" standards and thus acting outside the formal standardization system which ISO alone claims to represent. See ISO, International standards and "private standards," 2009.

78. See Allison Loconto \& Eve Fouilleux, Politics of private regulation: ISEAL and the Shaping of Transnational Sustainability Governance, 8 REG. \& GovERNANCE 166, 176 (2014); see also, Nicolas Hachez \& Jan Wouters, A Glimpse at the Democratic Legitimacy of Private Standards: Assessing the Public Accountability of GLOBAL G.A.P., 14 J. INT'L ECON. L. 677, 695-96 (2011). 
and, like self-regulators, have a conflict of interest inherent in their functions: they are there to serve the interests of their constituents but also the national interest. $^{79}$

Thus, without the necessary procedural guarantees in place, the beneficial effects of standardization can be undermined. If standardization cannot resist market power, it may ultimately increase barriers to innovation and market access. Therefore, mechanisms that maintain an adequate level of institutional sensitivity and accommodating structures to take into account important societal values and a multiplicity of interests are necessary. ${ }^{80}$

\section{A. ISO}

\section{The (One-Sided) Objective of ISO}

ISO was the first general international standardizing body ever created ${ }^{81}$ Its predecessor, the International Standards Association (ISA), a federation of the national standardizing associations, was mainly a club dominated by the continental European countries (the "metric bloc"). It evolved into a truly international body only after World War II. ${ }^{82}$ ISO is not an intergovernmental organization, which means that its output is deprived of any formal coercive force; rather, it is a network (or federation) of national SSBs, composed of both governmental and industry representatives. The ISO Secretariat is relatively small (137 full-time employees), serving a coordination function.

The purpose and normative point of the ISO is to promote the development of international standards with a view to facilitating trade and to developing cooperation with respect to intellectual, scientific,

79. See also, Trade Agreements Act of 1979, 19 U.S.C. $\S \S 2501-81$ (2012) (providing that "the representation of United States interests before any private international standards organization shall be carried out by the organization member." The latter is defined as "the private person who holds membership in a private international standards organization.”). See 19 U.S.C. § 2543 (quoted in Harm Schepel, The Empire's Drains: Sources of Legal Recognition of Private Standardization Under the TBT Agreement, in Constitutionalism, Multilevel Trade Governance And International ECONOMIC LAW 397, 404 (Christian Joerges \& Ernst-Ulrich Petersmann eds., 2011)).

80. Kenneth W. Abbott \& Duncan Snidal, International "Standards" and International Governance, 8 J. EUR. PUB. POL. 345, 349 (2001).

81. IEC, the ISSB dealing with standard-setting in the fields of electrical and electronic engineering, was established about half a century before ISO, in 1906. When established, ISO largely mirrored IEC's structure. Over the years, ISO and IEC became the twin organizations for international standard-setting, having a similar structure, common rules of procedure, joint technical committees and a common standardization grammar (the regularly revised ISO/IEC Directives, that is).

82. Craig Murphy \& JoAnne YATEs, The International Organization for STANDARDIZATION (ISO): GLOBAL GOVERNANCE THROUGH VOLUNTARY CONSENSUS (2009); see also Tim BÜthe \& Walter Mattli, The New Global Rulers - The Privatization of Regulation IN THE WORLD ECONOMY (2011), $126 \mathrm{ff}$. 
technological, and economic activity. ${ }^{83}$ Thus, collective action within ISO should be about enabling commerce to flourish. Therefore, its activity and overall assessment should be based on this normative point of collective action within ISO; that is, how to encourage market access for traders.

As it is, ends and means within ISO are very much economic, tradeoriented and in particular producer-oriented. This is to be expected, particularly when looking at the composition of national SSBs which are members of ISO but also the very essence of international technical standardsetting: it is the producers who feed the demand for international standards to alleviate costs. Indeed, traders are the main, if not only, demanders of international technical standards with a view to expanding market access, facilitating the smooth functioning of global supply chains, increasing interoperability and decreasing compliance costs. Other considerations such as those relating to safety or consumer protection, for instance, would be accounted for within national SSBs or domestic public regulatory authorities.

\section{ISO Membership}

ISO currently comprises over 160 members, predominantly national standardization bodies, involved in the development of standards. These bodies are of a hybrid nature, but primarily composed of representatives from the private industry, whereas government staff experts act as members in the national bodies. ${ }^{84}$ Again, this varies depending on the country's (centralized or decentralized) approach to technical standards. In the U.S., for instance, where ANSI is a private entity, ISO standards are regarded as standards adopted by and addressed to private parties. ${ }^{85}$ In Japan, on the other hand, it is the Japanese Industrial Standards Committee, an advisory council of the Ministry of Economy, Trade and Industry, that represents the Japanese interests to ISO. While under the auspices of the government, JISC is in reality a multi-stakeholder body.

Domestic structures influence the positioning of particular national interests within ISSBs. For instance, allegations that the EU dominates international standard-setting through its regional SSBs and a "block-voting"

83. ISO Statutes, 17th ed. (2013), art. 2.1.

84. See ISO, ISO Membership Manual, I-7 (2015), http://www.iso.org/iso/ iso_membership_manual.pdf (last accessed on Feb 19, 2017); see also, Steven Bernstein \& Erin Hannah, Non-State Global Standard Setting and the WTO: Legitimacy and the Need for Regulatory Space, $11 \mathrm{~J}$. INT'L ECON. L. 575, 587 (2008).

85. See David A. Wirth, The International Organization for Standardization: private voluntary standards as swords and shields, in RESEARCH HANDBOOK ON ENVIRONMENT, HEALTH AND THE WTO 139, 141 (Geert van Calster, Marie Denise Prévost eds., 2013). 
approach within ISSBs have been common. ${ }^{86}$ However, it was found that this observation most likely does not hold, or at least not to the extent argued by non-EU countries. ${ }^{87}$

For each country, ISO accepts only one member, which is also the representative of ISO in that country. ISO has three categories of members: subscriber, correspondent and full members (or member body). Full members can be either participating (P-member) or observing members $(\mathrm{O}$ member). Full membership means unrestricted rights in terms of standards development. Only full members can unconditionally participate and vote. However, full membership is highly unbalanced: some ISO members (ABENOR of Benin) only participate in one technical committee (TC), while other ISO members such as France, Germany or the United Kingdom participate in over 700 technical bodies, including TCs, subcommittees and working or ad hoc study groups. ${ }^{88}$

The degree of participation in these bodies varies: in some, the ISO member will hold the secretariat, whereas in others it is an O-member. In 2015, there were over 750 active secretariats. Germany, the U.S. and Japan appear to be sharing the lion's share of the workload - but also, importantly, influence. Overall, Europe has traditionally been more active and this still is the case. By way of illustration, the European standard-setting bodies held about half of ISO's active secretariats in $2015 .{ }^{89}$

Such participatory rights are not extended to subscriber and correspondent members. Correspondent membership (currently enlisting 38 national standards bodies) amounts to an observer status to ISO. Correspondent members can also sell and adopt ISO standards nationally. This category of members varies considerably as well, including countries in the process of becoming EU members (e.g., Albania) and over ten African countries. The least active category is subscriber membership (currently encompassing 5 national standards bodies), whereby the national

86. See ANSI, National Standards Strategy For the United States (2000).

87. See Jan Martin White, A "Single European Voice in International Standardization? American Perceptions, European Realities, Am. Inst. for Contemp. Ger. Stud. AICGS/DAAD Working Paper Series, 2003.

88. Interestingly, six out of the ten most active member bodies stem from the European Union. In addition, and to show the breadth of activities that ISO maintains, there were over 3,500 active technical bodies within ISO in 2015.

89. See ISO Figures, 2015. Interestingly, eight out of the twenty current ISO Council members are European standard-setters, representing countries of the European Economic Area (EEA). The ISO Council is the highest governance body of ISO, appointing, inter alia, the fifteen members of the Technical Management Board (TMB). Out of the eight national standard-setting bodies that participate in both the TMB and the ISO Council, three are European (Germany-DIN, France-AFNOR, and UKBSI). For the potential impact of the ISO-CEN Vienna Agreement, see infra under Section IV.B. 
representative standard-setter cannot participate in standard-setting within ISO. In addition, such bodies cannot sell or adopt ISO standards at the domestic level.

Recently, ISO decided to expand members' rights for the last two categories of membership for the years $2014-19 .{ }^{90}$ This decision exemplified ISO's attempt to allow for the less involved members to become acquainted with standards development processes, but also address concerns that were voiced with regard to lack of effective participation possibilities for developing countries, only for that time period, and without any additional charge, correspondent and subscriber members will be able to participate in up to five TCs; comment and vote on draft and final draft ISO standards prepared in these TCs in which they participate; as well as benefit from the ISO's “twinning” system through partnerships with P-Members. However, they will be unable to have any committee leadership roles, which, in any case, necessitate considerable savvy.

From the manner that this experimental scheme is structured, one can infer that ISO would expect these members to be actively involved. For instance, if they decide to take advantage of the new rights, they must participate in the TCs as P-members. O-membership is not permitted under this new scheme. This would mean, for instance, that at the end of the standards development process those members are obliged to vote (and thus take an informed stance) on draft standards.

In view of the high preparation costs for such a transition, the possibility of participating in the twinning scheme sounds more promising for the least emancipated ISO Members. The rationale behind the twinning system is that developing countries face many difficulties in playing a leadership role within ISO. Through partnerships with developed countries, a beneficial knowledge transfer will most likely take place. ${ }^{91}$ An example of a rather successful twinning is the ISO 26000 on social responsibility, whereby Brazil (Chair) teamed up with Sweden (Vice-Chair) to lead the Working Group that was created.

90. See OECD/ISO, International Regulatory Co-operation and International Organizations: The Case of the International Organization for Standardization (ISO), OECD (2016), at 23.

91. ISO, Guidance on Twinning in ISO Standards Development Activities: Increasing the Participation of Developing Country Members, ISO (April 2013). There are four types of twinning: between P-members; between convenors and co-convenors; between chairs and vice-chairs; and between secretaries and co-secretaries. The most recent version of the Guidance document was released in February 2017. 


\section{B. Standard-Setting Process in ISO}

\section{The Understated Political Element of ISO Standard-Setting}

Standard-setting resembles law-making. Standards, like laws, are the outcome of discussion, bargaining, deliberation and compromise. ${ }^{92}$ However, standards established by ISSBs like ISO are not law per se, but rather serve a clear regulatory function prescribing rules for others to follow. ${ }^{93}$ The standard-setting process within ISO - and, indeed, all ISSBsis a comprehensive regulatory function that not only sets the ends to be achieved through a particular international standard or "deliverable" but also is eloquent as to the means (technical for the most part) that should be used.

In other words, not everything about international standardization is technical; rather, international standardization has a political and technical dimension alike: the political process determines the ends to be pursued by materials, products, services, and processes, whereas the technical dimension relates to the means that are most appropriate to achieve an end. ${ }^{94}$ While it would be reductive to suggest that all ISO members stand on equal footing as to the technical part of the standardization process, it would be equally reductive to purport that the characteristics of the political process within ISO and the discussion (or lack thereof) of the ends pursued by a particular standard do not affect the authority of such standard and, ultimately, the authoritative collective action of ISO as a whole. ${ }^{95}$

2. The Various Stages of Standard-Setting within ISO

ISO standards are prepared within TCs. However, requests for the development of a given standard can originate in one or more national member bodies, a TC, a policy development committee such as DEVCO, the ISO Secretary-General, or even an organization outside ISO (for instance, another international organization). Development of a given standard is typically regarded as a stand-alone project that should be terminated in a

92. See Benedict Kingsbury et al., The Emergence of Global Administrative Law, 68 LAW \& CONTEMP. PROBS. 15, 15 (2005).

93. See Julia Black, Legitimacy, accountability and polycentric regulation: dilemmas, trilemmas and organisational response, in NON-STATE ACTORS AS STANDARD SETTERs 241, 246 (Anne Peters et al. eds., 2009).

94. See Efficiency and Accountability in European Standardization Under the New Approach, Report from the Commission to the Council and the European Parliament, COM (1998) 291 final (May $13,1998)$ at para. 7.

95. For a more thorough analysis of this particular argument, see Hans Lindahl, ISO Standards and Authoritative Collective Action: Conceptual and Normative Issues, in THE LAW, ECONOMICS AND Politics of InTERnATIONAL. STANDARDisATION 42 (Panagiotis Delimatsis ed., 2015). 
reasonable period of time. ${ }^{96}$ Standards can be developed in a new TC or in an existing one.

TCs are established by the ISO's technical management board (TMB). ${ }^{97}$ The TMB has fifteen member bodies appointed or elected by the ISO Council and is chaired by one of the ISO Vice-presidents. ${ }^{98}$ The TMB is in charge of managing the TCs. Consensus is desirable pursuant to the TMB Working Procedures, but a minimum of two-thirds majority vote may be sufficient. In the case of a tie, it is the TMB chair who decides. ${ }^{99}$ The TMB has a decisive role to play in deciding on the approval or not of project proposals relating to the future development of new standards and the allocation of work to TCs. In exercising its functions, the TMB can conduct informal exploratory enquiries to review the dynamics of a new potential project. The TMB will establish new TCs only if a two-thirds majority of the national bodies voting are in favor and at least 5 national member bodies have pledged to participate actively in the work of the TC. ${ }^{100}$ Every TC will normally have a Secretary and a Chairman. Secretariats are allocated by the TMB.

Because of the rather decentralized form of ISO, the Secretariat of a TC will be run by an ISO member body (for instance, the Association française de normalisation-AFNOR or the American National Standards InstituteANSI), which will appoint a Secretary and nominate a Chairman. ${ }^{101}$ This solution was initially opted for to bridge the gap between those national SSBs which wanted ISO to have a coordinating role and those who saw ISO as a powerful international standard-setter. ${ }^{102}$ In theory at least, the TC

96. See ISO/IEC Directives Part 1, Consolidated ISO Supplement-Procedures specific to ISO, 7th edition, ISO (2016), art. $2.1 \mathrm{ff}$ [hereinafter ISO/IEC Directives].

97. Id., at 1.9.1.

98. See ISO Statutes, $17^{\text {th }}$ edition (2013), art. 9. Current TMB members are (dates of term expiry included): ABNT (Brazil-2017); AFNOR (France-2017); ANSI (USA-2018); BSI (United Kingdom2018); DIN (Germany-2018); DSM (Malaysia-2017); GOST R (Russia-2018); JISC (Japan-2019); KATS (Korea-2018); SA (Australia-2019); SABS (South Africa-2017); SAC (China-2017); SIS (Sweden2017); SFS (Finland-2017); and SNV (Switzerland-2019).

99. TMB Working Procedures, February 2014, art. 4.2ff.

100. Thus, the voluntary character of international standards does not only relate to compliance with the final standard, but also to active participation in the development of such a standard.

101. Crucially, this important task can be further delegated to private parties. For instance, ANSI has procedures in place that allow the delegation to private parties of ANSI participation to ISO. See ANSI, ANSI Procedures for U.S. Participation in the International Standards Activities of ISO - annex B: Criteria for the Development and Coordination of U.S. Positions in the International Standardization Activities of the ISO and IEC, January 2017.

102. MURPHY \& YATES, supra note 82 , at 36. 
Secretariat is bound to act in a purely international capacity rather than serving the national point of view. ${ }^{103}$

Depending on the breadth of the workload, sub-committees or working groups may be created. Working groups are quite important and becoming a convener in those groups may influence the structure, content and form of the final standard. According to the ISO/IEC Directives (hereinafter "the Directives"), the convener will normally be the project leader and will ensure that, in a given period of time, a draft standard will be available for the subcommittee's and/or the parent TC's consideration.

There are over 230 active TCs within ISO. ${ }^{104}$ As the work of a given TC is very technical, having a bird's-eye view of developments in each and every TC is very difficult, if not highly unlikely. Typically, national SSBs are called upon to act as secretariats in technical committees. Secretariats are distributed unevenly, with ANSI and DIN (Deutsches Institut für Normung, ANSI's German counterpart) maintaining a disproportionally large number of such secretariats. ${ }^{105}$ By way of illustration, the German and American SSBs together account for almost forty percent of the active TC secretariats and convenerships. ${ }^{106}$

There are seven "project stages" that show the development of the technical work within a TC.

Table 1. The Stages of Standards Development within ISO

\begin{tabular}{|c|c|c|}
\hline \multirow[t]{2}{*}{ Project stage } & \multicolumn{2}{|l|}{ Associated document } \\
\hline & Name & Abbreviation \\
\hline $\begin{array}{l}\text { Preliminary } \\
\text { stage }\end{array}$ & Preliminary work item & PWI \\
\hline Proposal stage & New work item proposal ${ }^{\mathrm{a}}$ & NP \\
\hline Preparatory stage & Working $\operatorname{draft}(\mathrm{s})^{\mathrm{a}}$ & WD \\
\hline Committee stage & Committee draft(s) ${ }^{\mathrm{a}}$ & $\mathrm{CD}$ \\
\hline Enquiry stage & Enquiry draft ${ }^{\mathrm{b}}$ & $\begin{array}{l}\text { ISO/DIS } \\
\text { IEC/CDV }\end{array}$ \\
\hline Approval stage & $\begin{array}{l}\text { final draft International } \\
\text { Standard }^{c}\end{array}$ & FDIS \\
\hline
\end{tabular}

103. See ISO/IEC Directives, supra note 96, at art. 1.9.2.

104. A list of TCs can be found online: at http://www.iso.org/iso/home/standards_development/ list_of_iso_technical_committees.htm (last accessed on Feb. 2, 2017).

105. For the current figures, see ISO in figures 2015, online: http://www.iso.org/iso/ iso_figures_2015.xls (last accessed on Feb. 2, 2017).

106. Id. 


\begin{tabular}{l|l|l|}
\hline Publication stage & International Standard & ISO, IEC or ISO/IEC \\
\hline a These stages may be omitted. \\
b Draft International Standard in ISO, committee draft for vote in IEC. \\
${ }^{\mathrm{c}}$ May be omitted.
\end{tabular}

Preliminary work items are introduced by simple majority of the Pmembers. ${ }^{107}$ This can then develop into a new work item proposal which will be approved provided that a simple majority of the P-members in the TC agree and at least $4 \mathrm{P}$-members commit to actively contribute to the project (in TCs with over $17 \mathrm{P}$-Members, at least 5 P-members should make a commitment to this respect).

In the preparatory stage, a work draft will be prepared. In this respect, the creation of a working group and the appointment of a convener may be necessary. Once a Committee draft is ready, national member bodies of the TC (both P- and O-Members) have the opportunity to submit comments, and consensus building on the technical content is sought. Comments should be compiled and the TC secretariat is responsible for indicating the action taken on each of the comments received. Successive drafts will be discussed in this respect until consensus among the P-members of the TC is achieved. ${ }^{108}$ Once agreement is reached on the technical issues, an enquiry draft is circulated.

At the enquiry stage, the draft standard is circulated to all national bodies for a 3-month vote. Importantly, this is the first time that ISO members that do not participate in the relevant TC will see the draft standard. Votes can be positive or negative - or ISO Members can inform of their abstention. Positive or negative votes can be accompanied by technical comments (or technical objections, respectively). A two-thirds majority of the P-member votes of the TC and the presence of no more than $25 \%$ of negative votes of all ISO members leads to the approval of the enquiry draft. In practice, approval of at least $75 \%$ of the national bodies casting a vote is striven for. Crucially, negative votes not accompanied by technical reasons do not count.

This means that, in theory at least, a standard could pass this stage even in the-admittedly extreme, but still theoretically possible - case of abstention by all ISO members who are not participating in the relevant TC or in the presence of negative votes which raise non-technical concerns. This highlights the weight of P-Members' behavior participating in the TC, but

107. See ISO/IEC Directives, supra note 96, at art. 2.2.1.

108. As discussed infra section III.C, consensus within ISO does not imply unanimity, but rather "absence of sustained opposition." 
also undermines the importance of the political element in the technical standard-setting process. ${ }^{109}$

If no negative votes were received, ${ }^{110}$ the $\mathrm{TC}$ can proceed to the publication of the final standard. In case the above-mentioned criteria are not met, the TC prepares a final text after incorporating the new comments and suggestions received. This final draft international standard (DIS) will be circulated to national member bodies for approval (approval stage). The same criteria for approval apply at this stage with the only difference that comments are no longer accepted in case of a positive vote. Negative votes must again state the technical reasons for rejecting the final draft. Otherwise, they do not count. If the criteria (2/3 majority of P-Members of the TC and no more than $25 \%$ of negative votes cast) are not met, the draft standard shall be referred back to the TC. In this case, the TC can even cancel the entire project or resubmit a modified draft which will undergo all previous stages.

Alternatively, the TC may decide to publish the draft standard as a technical specification, particularly in a case of persistent opposition or doubt as to consensus. In practice, this may happen only in cases of receiving negative votes that state technical objections and exceed the $25 \%$ benchmark of the total votes cast. A technical specification shall not be in conflict with an existing international standard. Later on (typically every three years), it can be reviewed with a view to being adopted as an international standard, provided that the criteria are met.

Finally, in terms of deadlines, three different tracks for the development of standards are possible: 1$)$ the accelerated standards development track (24 months); 2) the default standards development track (36 months); and 3 ) the enlarged standards development track (48 months). The time runs from the date of adoption as an approved work item. ${ }^{111}$ In practice, standards development can last much longer, notably in cases of controversy.

A fast-track procedure is envisaged in the Directives, ${ }^{112}$ for instance, in cases of a standard developed in another ISSB that is recognized by the ISO or IEC Council. If the fast-track procedure is opted for, then the document can be submitted directly for vote as a draft international standard to the ISO members through the relevant TC or subcommittees (SC) (enquiry stage). That document can be submitted directly as a final draft international

109. See discussion supra section III.B.1.

110. Abstentions and negative votes do not count unless they raise technical objections. ISO/IEC Directives, supra note 96, at art. 2.6.3.

111. Id., art. 2.1.6.1.

112. Id., annex $\mathrm{F}(2)$. 
standard if the external ISSB is recognized by the ISO Council (approval stage). ${ }^{113}$

The fast-track procedure can in theory reduce the time needed for a standard to be adopted, but it can also lead to certain frictions in situations where a competing standard is discussed at the same time within the ISO "ordinary" standard-setting process. For instance, something similar happened in the process that led to the adoption of Microsoft's Office Open XML (OOXML) as an ISO standard (ISO/IEC 29500), overriding the effort of the proponents of Open Document Format (ODF) within ISO. ${ }^{114}$ In this respect, Microsoft was accused of attempting to circumvent the rules by first lobbying for the adoption of OOXML within Ecma International and then initiating the fast-track procedure taking advantage of the fact that Ecma International was an external Category A liaison body of the ISO/IEC JTC $1 .{ }^{115}$

\section{Collaborative International Standard-Setting}

ISO works in close collaboration with the IEC on all matters relating to electrotechnical standardization. While ISO and the IEC share the same set of directives, there are also directives which are specific to ISO or the IEC. In 1987, the first Joint Technical Committee (JTC 1) was created between ISO and IEC to prepare standards in the areas of ICT, including multimedia, ICT security, and cloud computing. ${ }^{116}$ Along with ISO and IEC, a third important standardization body is the ITU.

These three organizations are recognized as the only international standardization bodies in the field of technical standards for certain WTO Members, such as the EU. ${ }^{117}$ In 2001, ISO, IEC, and ITU established the World Standards Cooperation (WSC) with the goal of "strengthening and advancing the voluntary consensus-based International Standards system," 118 which they created through the avoidance of duplication and

113. ISO/IEC Directives, supra note96, at F.2.1.2.

114. See also Maija Palmer, Microsoft wins key ISO certification, FIN. TIMES (April 1, 2008), at https://www.ft.com/content/055e5bd0-0014-11dd-825a-000077b07658?mhq5j=e6 [https://perma.cc/ GU9L-GBVF]

115. Note that the JTC 1 has its own procedures for fast-track standard-setting and appeals. Notably with respect to appeals, within JTC 1, not only P-members but any member/national body can appeal against an action or inaction. See ISO/IEC Directives, supra note 96, at art. 5.1.2.

116. See ISO/IEC JTC 1-INFORMATION TEChNOLOGY, (last accessed on Feb. 15, 2017) at https://www.iso.org/isoiec-jtc-1.html [https://perma.cc/7SWA-CDAX].

117. See also EU Regulation 1025/2012, supra note 36, at art. 2 (9).

118. AвOUT, (last accessed on Feb. 15, 2017) at http://www.worldstandardscooperation.org/ about.html [https://perma.cc/V6AE-L38D]. 
overlap of work. The three ISSBs also cooperate in the area of patent policy by adhering to common guidelines. ${ }^{119}$

\section{Consensus Building in ISO}

Generally, ISSBs choose consensus as the decision-making mode par excellence, which ISO defines as "general agreement, characterized by the absence of sustained opposition to substantial issues by any important part of the concerned interests and by a process that involves seeking to take into account the views of all parties concerned and to reconcile any conflicting arguments." 120 (Emphasis added). However, it is made clear that consensus need not imply unanimity. In addition, the Directives consider sustained oppositions as a peculiar category of objection. They are defined as "views...maintained by an important part of the concerned interest and which are incompatible with the committee consensus." 121

The Directives call upon the leadership of the relevant body to solve the issue based on certain guidelines. For example, they require that the leadership of the committee ensure that the opposition is sustained by an important part of the concerned interest, which will vary depending on the dynamics of the relevant committee. If so, it should be dealt with in good faith. The right of opposing views to be heard is guaranteed in the Directives. However, and crucially, a sustained opposition is not akin to a right to veto. Thus, good-faith efforts are warranted, but progress of the committee work is not conditional on actual resolution of the issue.

Although unanimity is not required, most international organizations aim for consensus building and have those mechanisms in place in their constitutions and by-laws. ${ }^{122}$ However, consensus can cause delays, whereby competitors argue for their preferred solution or simply hold out until one side concedes or withdraws to the benefit of the other. ${ }^{123}$ Endorsement of a given standard at the end of the process can generate substantial rents, making the effort worthwhile ${ }^{124}$ but also confirming the value of the

119. See ISO/IEC Directives, supra note 96, at annex I.1.

120. Id. at art. 2.5.6. This definition is generally accepted as reflecting the current understanding of consensus in SSBs. See also EU Regulation 1025/2012, supra note 36, at annex II, ๆ 3(b).

121. See ISO/IEC Directives, supra note 96, at art. 2.5.6.

122. See Jens Steffek, Sources of Legitimacy Beyond the State: A View from International Relations, in TRANSNATIONAL GOVERnANCE AND CONSTITUTIONALISM 81, 94 (Christian Joerges et al. eds., 2004).

123. Farrell and Saloner first described this tactic as a 'war of attrition', suggesting that it may lead to the technically best solution, but with a significant delay. See Joseph Farrell \& Garth Saloner, Coordination through committees and markets, 19 RAND J. ECON. 235, 238 (1988).

124. Marc Rysman \& Timothy Simcoe, Patents and the Performance of Voluntary Standard-Setting Organizations, 54 MGMT. SCI. 1920, 1924 (2008). 
standard-setter as a stabilizing factor in its capacity as a coordinating authority.

In addition, it was shown that, in areas of rapid technological innovation with important rents at stake (distributional conflicts), the standard-setting process may be slower in a consensus-based standard-setting body, but delays are efficient when the underlying technology improves over time. Therefore, and quite importantly, at the end of the lengthy process it is likely that higher quality outcomes will be produced. ${ }^{125}$ This means that, contrary to conventional belief, and somehow counterintuitively, striving for consensus may have a very limited impact on the technical and scientific excellence of a given standard. However, when vested interests are strong, relaxing the consensus requirement or identifying a neutral participant to break the deadlock (i.e., binding arbitration or appeal mechanisms) may be preferable to increase the effectiveness of a given standard. ${ }^{126}$

In practice and as explained earlier, ISO does not decide by unanimity or even consensus, but rather has adopted qualified majority voting rules in the various stages (from the preliminary stage to the enquiry draft and up to the publication stage) that lead to the adoption of an international standard. ${ }^{127}$ According to the Directives, within ISO, if there is doubt as to whether consensus was reached for registration as an enquiry draft (that is, the TC draft), a two-thirds majority of the actively involved members ("Pmembers") in the TC approving it would suffice. ${ }^{128}$

The "two-thirds rule" of the active members and the $75 \%$ of votes cast seem to be generally applicable. Thus, rather than unanimity, these qualified majority voting modalities should be regarded as the general benchmark expressing the multilateral scientific consensus in the international technical standardization community. In line with this observation, a final draft international standard circulated by a TC is approved if two-thirds of the votes cast by the P-members in the TC (rather than of the entire ISO membership) are in favor and not more than one quarter of the total number of votes of national member bodies cast are negative. The two conditions are cumulative. Abstentions do not count and the same goes for negative votes that are not based on technical reasons. ${ }^{129}$ This applies to both the enquiry stage and the approval stage. This means that objections with respect to procedural defects, for instance, would need to be raised at an early stage

125. Timothy Simcoe, Standard Setting Committees: Consensus Governance for Shared Technology Platforms, 102 AM. ECON. REV. 305, 331 (2012).

126. Farrell \& Simcoe, supra note 70 , at 246.

127. See ISO/IEC Directives, supra note 96, at cl. 2.

128. Id. at cl. 2.5.6.

129. Id. at cl. 2.7.3. 
(i.e., at the moment that the relevant TC or subcommittee still discusses drafting). This is also made clear in the Directives of 2015, which provide the following:

...to avoid re-discussion, national bodies have the responsibility of ensuring that their technical standpoint is established taking account of all interests concerned at national level, and that this standpoint is made clear at an early stage of the work rather than, for example, at the final (approval) stage. Moreover, national bodies need to recognize that substantial comments tabled at meetings are counter-productive, since no opportunity is available for other delegations to carry out the necessary consultations at home, without which rapid achievement of consensus will be difficult. ${ }^{130}$

However, for this to be possible in the first place, effective participation is a prerequisite. Effective participation would include the ability to be at all meetings, to follow several meetings simultaneously, which may be organized in different places around the world, and to find the way through a large number of technical documents in a short period of time.

\section{Other Procedural and Substantive Guarantees}

The Directives incorporate expressis verbis a right to appeal against decisions on new work items, committee drafts, enquiry drafts, or final draft international standards within 3 months from the decision at issue. However, and quite crucially, this right to appeal is not unqualified; rather, it is reserved exclusively for P-Members. The TMB is in charge of considering such appeals. Appeals can be filed by P-Members only on condition that they are against the Statutes and Rules of Procedure or the Directives, or detrimental to trade, safety, health or the environment. Appeals can relate not only to technical but also to administrative issues. However, they do not have suspensive effect, as the standards development can continue up to and including the approval stage. ${ }^{131}$

In addition, appeals against new work items, committee drafts, enquiry drafts, or final draft international standards are accepted only if they relate to technical matters or the reputation of ISO is at stake. ${ }^{132}$ When it comes to issues that must be answered in the negative or the affirmative, approval by the TMB requires that at least two-thirds of the total votes be positive. ${ }^{133}$

130. Id. at 5 (emphasis added)

131. Id. at cl. 5.5.

132. See id. at cl. 5.1.3 (suggesting in the provision that the appeal should relate to a 'question of principle.' A teleological/contextual interpretation, for instance, the privileged rights of P-members or the fact that negative votes do not count unless they are based on technical reasons, would suggest that this equates to technical reasons). Id.

133. See TMB Working Procedures, supra note 99, at cl. 4. 
Abstentions within the TMB are generally discouraged. If the TMB is in favor of moving forward with the appeal, a conciliation panel is established. The panel should resolve the dispute within a maximum of 6 months or refer the issue back to the TMB with its recommendations as to how the issue should be settled. The decision by the TMB can be appealed before the ISO Council Board. The decision by the latter on any appeal should be delivered within 3 months and is final.

Furthermore, the Directives provide for a fairly detailed procedure that should precede the establishment of a new TC or the adoption of a new work item notably focusing on adducing evidence to substantiate the necessity thereof. The onus in this case lies with the proposer, particularly in establishing a substantial case about the "market relevance of the proposal."134 Obviously, the level of detail in such proposals will vary, depending on the availability of technical knowledge and the existence of work previously conducted within ISO or elsewhere. Annex C of the Directives includes various procedural and substantive guarantees relating to the introduction of new work items (specificity of the proposed item; relation to and impact on existing standards or work items; an indication of possible participating countries; an indication of stakeholders and so on) that aim to ensure the viability of the new work item and spell out the need for, as well as the global relevance of, a new standard in a particular area. The Directives provide a list of documents that can be submitted such as statements explaining the technological, economic, societal, and environmental benefits of a proposed standard. ${ }^{135}$ However, the proposer is not bound by this list; rather, the proposer shall make first and foremost a substantial business case for the market relevance and need for a given proposed standard.

In its continuous attempt to maintain its relevance, ISO has established two policy committees to inform its standardization work.

First, the ISO Committee on developing country matters (DEVCO) was created in 1961. DEVCO currently has 101 participating and 52 observing member bodies and meets annually. DEVCO also monitors the ISO Action Plan for developing countries. ${ }^{136}$ In accordance with ISO's practice, PMembers have the upper hand in the discussions and actions, whereas many African countries but also other developing and least developed countries, having the status of correspondent members within ISO, can only participate as observers (O-members) and thus have no meaningful say. These countries

134. ISO/IEC Directives, supra note96, at annex C, C.3.2.

135. Id. annex C, C.4.13.3.

136. See Int'l Org. for Standardization [ISO], Action Plan for Developing Countries 2016-2020, at 3 (2016). 
cannot participate, nominate experts, nor be in a chair's group within the DEVCO.

Second, the ISO Committee on Consumer Policy (COPOLCO) was created in 1978 and currently has 68 participating and 56 observing member bodies. To date, COPOLCO has published 7 standards (mostly guides on how to take into account consumer issues when developing standards) under its direct responsibility (including updates of previous editions of guides). Direct links with consumers at the national level are rather weak or, for certain countries, non-existent. ISO, however, expects that consumer interests are taken into account at the level of the national standards body. ${ }^{137}$ When consumer-related issues are important elements of the development of an international standard, national standards bodies should consider including consumer representatives in their delegation. ${ }^{138}$ It seems that the involvement of consumers and consumer associations at the domestic level is a function of the sophistication of the national standards body. ${ }^{139}$ Be that as it may, COPOLCO is currently a committee where only ISO Members, that is, national standard-setting bodies, and no consumer associations are represented.

Furthermore, the Directives provide for the regular review of international standards that should take place every 5 years at the latest. The review should not last more than 5 months and ends with a decision by the relevant committee to revise, confirm, or withdraw the standard at issue. For confirmation, the threshold is rather low: use in at least 5 countries and positive vote by the simple majority of the P-members participating in the committee. If these members call for amendments to the standard, then the revision process is initiated. Use of the standard at issue in less than 5 countries should lead to the withdrawal of that standard.

Finally, it is worth mentioning that due to the importance of protecting intellectual property rights in standardization activities, ISO, ITU and the IEC agreed on a common patent policy in 2007 to address the problems associated with standard-essential patents (SEP). ${ }^{140}$ In this case, substantive guarantees for intellectual property protection include the right of the patent holder to deny access to her protected right (and thus the final draft standard

137. See, e.g., ISO, Guidance for national standards bodies - Engaging stakeholders and building consensus, at 8-9 (2010).

138. See ISO/IEC, Statement on consumer participation in standardization work, ISO/IEC/GEN $01: 2001$.

139. See, e.g., ISO, Involving consumers - Why and how, at 10-11 (2011); see also CEN/CENELEC, Guide 2: Consumer Interests and the preparation of European Standards, at 1-2 (1st ed., Dec. 2001).

140. See ISO/IEC Directives, supra note 96, at annex I. 
should not include provisions depending on the patent right) or to disclose her rights and then negotiate licensing and the level of royalties under fair, reasonable and non-discriminatory terms (FRAND). ${ }^{141}$ The policy of ISSBs in principle would entail a hands-off approach: patent holders would be entitled to defend their rights vis-à-vis potential users; yet, due to the importance of the standard that is based on the patented input, the holders of that patent would be required to negotiate agreements on the use of such patents on FRAND terms outside the ISSBs.

In other words, bilateral agreements or settlement are encouraged but not administered by the ISSBs. Various issues of competition law nature can be of importance in this regard, including non-disclosure of patented rights in order to extract higher royalties once the standard is adopted; prohibitive royalties which in effect limit market access; abuse of dominant position and so on. Again, these are issues that would be scrutinized by domestic competition authorities and subsequently by courts rather than the ISSBs themselves. $^{142}$

\section{AN ASSESSMENT OF ISO'S STANDARDIZATION-RELATED PRACTICES}

\section{A. ISO at the Crossroads}

ISO has been at the forefront of international rule-making in recent years. In view of the importance of technical standards for economic development and sustainable growth, limited participation and effective exclusion in ISO standard-setting activities have sparked debate. More recently, considerable efforts were made to increase effective participation but also expand the substantive subject matter of the organization to include less technical areas such as those relating to the environment, labor, or human rights. ${ }^{143}$

All in all, the ISO standard-setting process seems to be quite streamlined, but various, significant issues remain. For instance, recall that 5 P-members suffice for the creation of a new TC. This would mean, at least in theory, that 3 P-members (simple majority) would be able to approve a

141. See generally, Patrick D. Curran, Standard-Setting Organizations: Patents, Price Fixing, and Per Se Legality, 70 U. CHI. L. REV. 983, 991-4 (2003).

142. See Case C-170/13, Huawei Tech. Co. Ltd. V. ZTE Corp., Judgment of the Court of July 16, 2015 (CJEU) (discussing the rights and obligations of a SEP holder).

143. See International Organization for Standardization [ISO], International Guidance Standard on Social Responsibility - ISO 26000 (Nov. 2010); STEPHANIE BIJLMAKERS \& GEERT VAN CALSTER, You'd be surprised how much it costs to look this cheap! A Case-Study of ISO 26000 on Social Responsibility, The Law, Economics and Politics of International Standardization 275, 275-310 (Delimatsis ed. 2015). 
new work item. ${ }^{144}$ Again, as noted above, a minimum of 4 P-members would be needed to commit that they will participate actively in the preparation of the new standard. Even so, in an organization of over 160 member bodies, this is too low a threshold. In addition, note that a two-thirds majority (following our example, that is, 3 out of the 4 P-members!) would suffice to bring forward the draft standard as an enquiry draft. This would mean that, in theory, $3 \mathrm{P}$-members could lead the entire process up to the enquiry stage.

Crucially in practice, all ISO members (that is, not only the relevant TC members) will see the draft standard for the first time at the enquiry stage. At that moment they merely have three months to raise technical objections and seek changes. In view of the low threshold applied, it is questionable why comments should be limited to the technical aspects of the standard. Procedural deficiencies should be allowed to be raised by the membership at this level as well, all the more because these could not be raised earlier. With so many committees working simultaneously on a broad array of topics, one would reasonably assume that many members would become familiar with a particular standard proposed for the first time during this 3-month period of voting. Depending on the complexity of the technical content involved, while for some ISO members the time may be sufficient, for others (who lack a high level of sophistication in technical matters) three months would rather short period of time to get acquainted with complex technical matters. Acquisition of technical information in such a short period of time becomes so costly that members prefer not to seek acquiring the necessary information at all. If members know that their vote will not influence the final decision, they will not invest in information. ${ }^{145}$

One could argue here, that even at that stage, ISO members could still express their disagreement to avoid the adoption of a shaky standard. In addition, P-members that participated in the TC work have a strong incentive to prepare a first-rate enquiry draft to compensate for the high start-up costs, but also because the more time they invest in preparing such a draft, the higher their interest is for such a draft to be of high quality so that it is accepted more easily. Furthermore, allowing voting at a very early stage may jeopardize the entire standard-setting process by making it overly political. ${ }^{146}$

Thus, from this point of view, allowing any objections to be raised for the first time at the enquiry stage does not constitute any serious prejudice

144. See ISO, supra note 143 at cl. 1.5.7 in conjunction with cl. 2.3.5.

145. See Nicola Persico, Committee Design with Endogenous Information, 70 REv. ECon. StUD. 1, 18 (2003).

146. See David Stasavage, Open-Door or Closed-Door? Transparency in Domestic and International Bargaining, 58 INT'L ORG. 667, 670 (2004) (stating that transparent procedures may lead certain agents to posture by taking uncompromising positions that may lead to deadlock). 
on the non-participating ISO members in the TC. This may also be in line with the spirit of ISO voting: ISO does not introduce a general decisionmaking system, but a de facto supermajority system whereby votes presuppose information acquisition. It is contestation on the technical grounds that can improve a given standard - and such contestation can even occur at the enquiry stage.

Both views presented here have their value and are sensible. However, even if the latter view is correct, no plausible reason seems to exist that would prevent TC members from sharing information with all ISO members about work on a new standard early on. For instance, while the committee draft stage seems to be quite important and various procedural guarantees are in place (for instance, prompt notification; notice and comment procedures; requirement to respond to all comments; revisions to be subsequently circulated), this stage is limited to the ISO members participating in the relevant committee. Whereas the committee draft stage appears to play a crucial role in line with the core principles of due process, the Directives suggest that, under certain circumstances, this important stage can be skipped if consensus (as defined within ISO) among the P-members is achieved. ${ }^{147}$

A notification requirement towards all ISO members would constitute a procedural guarantee with immediate positive impact on the substantive rights of other ISO members. Such information, for instance, could be publicly available on the ISO website with a short, expedited notification/alert system. In extreme cases of opposition within a TC, early (perhaps indicative) voting could act as an alternative buffer that allows certain standards to move forward, provided that the broader ISO membership supports them despite opposition within the TC. Finally, objections should be allowed to be raised-and appeal procedures should allow for that - if any ISO member can prove serious prejudice to its rights.

Significant path dependencies remain within ISO, as the previous analysis demonstrated, alluding sometimes to the need for a shift in ISO's modus operandi: for one, the political dimension of ISO standard-setting appears not to be yet of immediate concern for the ISO leadership. This becomes obvious when we look at the imbalances between the rights of Pmembers, on one hand, and the other ISO members, on the other; the late notification of draft standards to all ISO members (inquiry drafts); the lack of any weight being given to negative votes which are not based on technical considerations; or, again, the limited possibilities for appeals which are not premised on technical grounds. Whereas the requirement for giving reasons

147. See ISO/IEC Directives, supra note 9696, annex SS. 
is generally of a due process nature and aims at limiting arbitrary objections and delays, the non-participating ISO members in the relevant TC would more often than not ignore basic technical features of a particular standard that is presented to them as an inquiry draft. Those participating actively (Pmembers), on the other hand, would have the necessary information.

It seems that attempting to remedy this asymmetry of information at the enquiry stage only is irrational. Rather, it achieves the opposite of what an inclusive international organization should be striving for: it appears to accentuate the gap between the more sophisticated - technically speakingISO members, and those which struggle to build capacity. The latter (admittedly, less informed members), when facing an enquiry draft would prefer to abstain ${ }^{148}$ or even cast a positive vote, ${ }^{149}$ which nevertheless is not necessarily based on a full grasp of what the standard stands for. Thus, the requirement for giving technical reasons appears to function as a presumption of fitness for purpose of the enquiry draft. This presumption is rebuttable, but obviously not many ISO members will have the capacities and knowledge to rebut effectively.

This excessive focus on the technical aspects of standardization and late notification of proposed draft standards may lead to undue dominance of certain ISO members - most likely the sophisticated ones. This approach offers little in the effort to establish more inclusive forms of governance at the international level. This situation may perpetuate even at the postadoption stage: at the moment of review of a given standard, the use of a given standard by just 5 countries would be sufficient for a standard to be regarded as an international standard of global relevance for ISO purposes. Other than the practice of exclusion that such a low threshold implies, it is also indicative of generally low thresholds that are set by the Directives with respect to key aspects of standard-setting, as mentioned earlier.

Active participation is one of the ISO principles according to the ISO Code of Conduct for the technical work. ${ }^{150}$ This justifies the privileged status that P-members enjoy within ISO - a kind of reward for their willingness to invest in promoting standard-setting (e.g., through active participation in the

148. In that case, because voting becomes costly for the uninformed voters (the price for acquiring information), they prefer to delegate their votes to the informed ones. See Timothy J. Feddersen \& Wolfgang Pesendorfer, The Swing Voter's Curse, 86 AM. ECON. REV. 408, 408-10 (1996) (describing the behavior of uninformed voters in choosing between political candidates).

149. For instance, they may cast a positive vote if they believe that the promoters of the standard would not jeopardize their reputation to bring forward for voting a standard of dubious quality. See Gilat Levy, Decision Making in Committees: Transparency, Reputation, and Voting Rules, 97 AM. ECON. REV. 150, 150-52 (2007).

150. International Organization for Standardization [ISO], ISO Code of Conduct for the Technical Work (2016). 
early stages of new work items; the running of secretariats, convenerships, or other leadership positions; or the posting of technical comments). This, however, neglects at the same time to acknowledge that standard-setting is inextricably linked with learning-by-doing; effective participation on a broader basis will never occur without capacity-building. This is the reason why the system of twinning is a noteworthy initiative that may changeeven if only at a slow pace - the ecology of international technical standardsetting, just as regional standard-setting initiatives in the developing world have. The case of the EU is telling in this respect. It is by now accepted that the empowerment of the European standard-setting bodies through the New Approach within the EU also had beneficial effects for the weight of the EU's bargaining power within ISSBs.

Participation in standard-setting is not only a matter of states, but very much of non-state actors, including industry, consumer or labor associations, NGOs, or other private interest groups. ISO claims to carry out its work in an "international, multi-stakeholder, multi-sector environment." Nevertheless, in principle, ISO would encourage its members to involve stakeholder interests at the national level, which then would have to be taken into account when preparing the national position of the representative SSB at ISO. With respect to consumer interests, COPOLCO has been active in addressing consumer-related aspects of standards by publishing guides instead of ordinary ISO standards. COPOLCO works under the ISO general Secretariat's responsibility, which appears difficult to square with the member-driven tradition of ISO.

In the face of increasing criticism, ISO has attempted to open up its doors to consumers directly. For instance, Consumers International, a global federation of consumer organizations from over 110 countries, has established a liaison with COPOLCO. The relationship, however, is rather asymmetrical, with P-Members still leading the discussions and ensuing decisions within COPOLCO. This approach becomes increasingly untenable: as noted earlier, whereas producers used to be the only demanders of international standards, nowadays consumers also seek the adoption of international standards that take their concerns into account. Increasing labor mobility and cross-border safety concerns due to defective products can indeed lead to more proactive advocacy on the side of consumers at the international level. The same goes for labor organizations in certain areas of

151. Id. 
ISO standard-setting, such as management and production systems. ${ }^{152}$ Thus, groups other than producers may have a substantial interest in participation.

In addition, the expansion of the ISO agenda may lead to awkward results in view of the upgrade that the ISO output has experienced after the adoption of the TBT agreement. This became particularly apparent in the negotiations that led to the promulgation of the ISO 26000 guidance document on social responsibility. ${ }^{153}$ Although generally regarded as an international standard for ISO purposes, the document clarifies that it must not be considered as such for the purposes of the TBT agreement. Nor is it intended to provide a basis for any assumption or finding that a measure is consistent with WTO obligations, thereby discrediting the value of Article 2.4 TBT when assessing this particular ISO deliverable. As noted in the relevant literature, this exercise of self-restraint vis-à-vis the TBT agreement by ISO was the result of intense negotiations within the multi-stakeholder working group on social responsibility to limit the scope of the final product. ${ }^{154}$ However, one wonders whether this is the price to pay for a more open approach on standard-setting and if so, what repercussions it may have on the relationship between ISO and WTO if such an approach spills over beyond guidance documents.

Experimenting with new forms of standard-setting such as multistakeholder standardization may be time-consuming, as it brings with it new ethos in the discussions, and thus takes traditional standard-setters - that focus predominantly on the technical aspects of the deliverables - out of their comfort zone. As the negotiations on the ISO 26000 showed, learningby-doing has its consequences: it took about six years to finalize the guidance document, which is of a softer nature than a traditional ISO standard, as it cannot be used for third-party certification.

Even so, the ISO 26000, with its "alternative production line" model, is a worthwhile standard-setting effort in view of the interests that were gathered to shape it: experts from more than 90 countries and 40 international or broadly-based regional organizations representing governments, NGOs,

152. Of course, questions of legitimacy, representation, participation and accountability can equally be raised with respect to consumer and labor organizations pointing to the need for benchmarking and potential reforms. In an era of increased legalization of rule-making at the international level, no actor active at this level is immune from such scrutiny. However, exclusion clearly is not an answer to such potential problems, all the more because evidence in certain sectors shows how important the background of standard-setters is for the final design of the standard. See Abigail Allen \& Karthik Ramanna, Towards an Understanding of the Role of Standard Setters in Standard Setting, 55 J. ACCOUNT. ECON. 66, 79-81 (2013) (examining the role of individual standard setters on accounting standards).

153. See ISO supra note143.

154. See BIJLMAKERS \& CALSTER supra note 143, at 300. 
consumer associations, industries, and so on came together to agree on a single guidance document. ${ }^{155}$ For ISO, this exercise is not only a matter of substance and scope, but also a matter of continuing relevance: with everincreasing competition coming from ISEAL alliance, GlobalG.A.P., ${ }^{156}$ and other newcomers in the standard-setting market and with much focus shifting towards sustainability of production methods and global supply chains, ISO cannot simply disregard these voices. ${ }^{157}$ Although these relatively new selfregulatory bodies have a different, partly morally motivated background, ${ }^{158}$ their ever-growing appeal may reveal shifts in moral preferences that cannot be overlooked. Therefore, it appears opportune that ISO expands its agenda and, by implication, the interests represented at the standard-setting table in view of its dominant position in this area of transnational rule-making. ${ }^{159}$ Excluded voices within ISO will most likely default if they see that chances of being heard are low. In such cases, they will look for other opportunities to fill what they perceive as a lacuna in international standard-setting matters. ${ }^{160}$

B. Reviewing ISO Practices Against the Principles of the TBT Committee Decision

Respect of the TBT principles on the development of international standards may have the same result. Interestingly, the ISO Code of Conduct adheres strictly to the six TBT principles: ${ }^{161}$ transparency; openness; impartiality and consensus; effectiveness and relevance; coherence; and the "development dimension" (that is, as noted earlier, the requirement to address the concerns of developing countries) figure prominently in the ISO's Code of Conduct. These principles have been upgraded to become

155. Participation, however, has been unequally distributed, with industry and governments together appointing about half of the experts in the Working Group. See Bart Slob \& Gerard Oonk, The ISO Working Group on Social Responsibility: Developing the Future ISO SR 26000 Standard, SOMO Briefing Paper, Mar. 2007, at 2.

156. G.A.P. stands for good agricultural practice. See Hachez \& Wouters supra note 78, at 679.

157. See Panagiotis Delimatsis, Sustainable standard-setting, climate change and the TBT Agreement, in The Research HandBook on Climate Change AND TRADE LAW (Panagiotis Delimatsis ed., 2016), 148.

158. Cf. David P. Baron, Morally Motivated Self-Regulation, 100 AM. ECON. REV. 1299, 1299 (2010).

159. See generally, Richard B. Stewart, Remedying Disregard in Global Regulatory Governance: Accountability, Participation, and Responsiveness, 108 AM. J. INT'L L. 211 (2014).

160. Albert O. Hirschman, EXit, Voice, AND Loyalty: Responses to DeCline in Firms, ORGANIZATIONS, AND STATES (1970).

161. See ISO Code of Conduct supra note 150150. 
"the key principles of international standardization."162 Thus, not only are the TBT principles endorsed by ISO, but they have also allegedly become guiding principles for its technical work. ${ }^{163}$

If this is a correct assumption, then no proper interpretation of these principles can take place without reference to the initial source document of these principles, which is the TBT Committee Decision. ${ }^{164}$ In other words, these principles do not have an ISO-specific meaning, but rather a WTO meaning, as elaborated in the TBT Committee Decision of 2000, subsequent meetings of the TBT Committee (e.g., the triennial reviews of the TBT Agreement) and as spelled out in the Panel and Appellate Body rulings such as the US-Tuna II ruling or future WTO disputes on TBT matters. ${ }^{165}$ The successful achievement of the trade-enabling objectives of the TBT agreement passes through the development of international standards, which in turn raises the bar as to due process expectations within ISSBs. ${ }^{166}$

With respect to the first two principles, the Decision is indicative of WTO Members' intent to ensure that the development of international standards takes place transparently and through wide participation.

With regards to transparency, the TBT Committee Decision requires that adequate time and opportunities be provided for written comments. In addition, the Decision appears to require dissemination of relevant information to all members of the standard-setting body early in the standard-setting process, much earlier than the current ISO procedures would provide. When this principle is assessed against the ISO practices, there seems to be room for major improvements in the ISO mechanics.

In the first reaction by ISO to the TBT Committee Decision, ISO turned a deaf ear to the requirement of transparency as enunciated in the Decision. It recalled its decentralized nature to claim that it is for ISO member bodies

162. Id. at 4 .

163. Note that ISO has an observer status at the TBT Committee and regularly informs the Committee of its activities and plans.

164. See WTO, TBT Committee, supra note 39.

165. The TBT Committee Decision appears to reflect WTO Members' prevailing normative view as to standards development. In the current NAMA negotiations, the Decision has informed Members' positions regarding the definition of international standards and the traits of ISSBs. See WTO, Negotiating Group on Market Access, 'Market Access for Non-Agricultural Products - International Standardisation', Communication from the European Union, India, Indonesia, Norway, Philippines, Switzerland and Thailand, WTO Doc. TN/MA/W/142, 13 April 2011.

166. See US - Tuna II, supra note 1817, at n.745 ("WTO Members see representative participation and the observance of due process in the development of international standards as essential to the achievement of the trade facilitating objectives of the TBT Agreement."). 
to inform domestic constituents, ${ }^{167}$ thereby neglecting the importance of direct communication and information channels that should be in place in view of the normative power that ISO has gained in the last two decades and the increasingly prominent role that it plays in international economic governance as a key trade-enabling institution.

Admittedly, ISO's move towards a more assertive role in international matters is slow. To date, ISO's approach vis-à-vis transparency and participation seems to be based on the publication of guides addressed to the national standard-setting bodies calling for more effective communication channels and dissemination of ISO's work at the national level, as well as for the adoption of an inclusive multi-stakeholder philosophy when establishing the national stance on a given subject discussed within ISO. It is doubtful at best whether this approach would be regarded as consistent with the TBT Committee Decision if it were put to test before the WTO judiciary.

With respect to openness, the Decision requires the existence of meaningful opportunities for participation at all stages of standards development. ${ }^{168}$ According to ISO, it is for ISO members to assess their technical capacity and accordingly decide their membership status (O-, P-, subscriber or correspondent membership). While ISO is probably right to argue that "it is neither effective nor efficient to have all developing countries participate in all standard-setting activities at the international level,"169 there is a clear imbalance in the distribution of technical work and leadership tasks within ISO, which obviously mirrors decades of knowledge acquisition on the side of developed countries.

While it is indeed sensible to encourage developing countries to organize themselves at the regional level hoping for better representation at the ISO level, schemes and mechanisms that would offer direct access to ISO standardization activities are necessary. The mechanism of twinning can only be considered as a necessary but insufficient instrument towards more effective participation. In addition, effective participation implies a significantly costly endeavor: absent financial means directed towards facilitating more regular participation by a broad ISO membership base, much of the work within TCs is dominated by industry-driven developed

167. See ISO/IEC Directives, supra note 96, at cl. 1.7.1.; see also WTO, TBT Committee, supra note 39 , at para. 6. After more than ten years, ISO's approach on the matter remained unchanged. See WTO, TBT Committee, 'ISO and IEC Comments on India's Submission on International Standard (IS) Setting', WTO Doc. G/TBT/GEN/129, Apr. 2, 2012, at para. 5.

168. See US Tuna-II, supra note18, at $9369 \mathrm{ff}$, at 142.

169. See WTO, TBT Committee, supra note39, at 6. 
country interests which have the necessary financial means to hold convenerships or TCs. ${ }^{170}$ Such embedded practices have led certain scholars to talk of transnational corporate domination ${ }^{171}$ of the process of drafting standards. This phenomenon may be worrisome in terms of fairness and participation, but, more fundamentally, of legitimacy.

The Decision further clarifies the importance of impartiality and consensus-building in ISSBs. Whereas it underlines the importance of meaningful opportunities to contribute to the elaboration of an international standard so that the entire process does not tilt towards the preferences of the few, it is more accommodating with respect to consensus, acknowledging indirectly that a decision-making system that takes into account the views of all parties concerned and seeks to reconcile conflicting arguments can meet the requirement enshrined in the Decision. Thus, the ISO's double consensus (as noted earlier, two-thirds rule within the TC and $75 \%$ of the votes cast) seems to meet the requirement of consensus within the Decision.

Recently, it was proposed that ISSBs follow the WTO consensus rule (a negative vote would amount to a veto right) or increase the threshold for adoption. ${ }^{172}$ ISO was not in favor of changing a decision-making system in which objections were a rare phenomenon. Within the WTO, the idea of raising the threshold does not seem to gather sufficient support, all the more because the underlying rationale is everything but clear. Rather, WTO Members seem to agree that, more fundamentally, it is about arguments rather than votes. Therefore, setting minimum benchmarks for consensus would be rather pointless. ${ }^{173}$ One can only agree with this observation: raising the minimum percentage of consensus would leave the problem of varying and unbalanced expertise within the ISO community intact. Opposing voices would still need to refer to technical reasons to challenge any given standard - and for that, a sophisticated level of capacity-building and ensuing expertise would be warranted.

A further source of future concern for ISO may potentially be an observation by the Appellate Body in US-Tuna II made in passu. As noted

170. See also RoHT-ARriAZA, supra note 68 , at 267.

171. Id.

172. India suggested that this threshold cannot be lower than $90 \%$. See WTO, TBT Committee, Principles of International Standard Setting, WTO Doc. G/TBT/W/345 (Nov. 10, 2011), at 2.

173. See the discussion within the TBT Committee in WTO, TBT Committee, Minutes of the meeting of 10-11 November 2011, WTO Doc. G/TBT/M/55 (Feb. 2, 2012), at I 285ff, https://docs.wto.org/dol2fe/Pages/FE_Search/FE_S_S009-DP.aspx?language=E\&CatalogueIdList= $89001,43462,51482,89194,92796,80305,97330,86176,98233,60846 \&$ CurrentCatalogueIdIndex $=1 \&$ Full TextHash $=\&$ HasEnglishRecord $=$ True $\&$ HasFrenchRecord $=$ True $\& H a s$ SpanishRecord $=$ True [https://perma.cc/LTM3-KL8X]. 
earlier, the US argued that AIDCP, the standard suggested by Mexico, was not a relevant international standard for various reasons, including because it did not allow for the participation of consumer and conservation interests in its standard-related activities. ${ }^{174}$ Arguably, for the resolution of the dispute, it was immaterial whether the Appellate Body ruled on that claim. Astonishingly, the Appellate Body decided to go on and answer the US claim. Without any meticulous analysis, it agreed that an international body must not privilege any particular interests when developing international standards. The Appellate Body premised its finding on the heading of the TBT Committee Decision relating to impartiality and consensus. ${ }^{175}$

However, a proper interpretation of that particular heading and of the previous drafts reveals that Members were unwilling to broaden so extensively the circle of relevant entities participating in the standards development process. Rather, the Members were concerned with the very effective access of their national or local standard-setting bodies to international standardization. Consumer associations or preservation-related NGOs did not seem to be within the circle of participants in the standardsetting processes that the WTO Members envisaged when adopting the TBT Committee Decision.

Thus, whereas the Appellate Body erred in this particular regard, a further confirmation of this finding in a future WTO dispute will be problematic for ISO. While generally open, as noted earlier, the ISO still does not allow such a great variety of interests to participate in the ISO processes. The constitution and function of COPOLCO (discussed earlier) illustrates this point quite powerfully. Indeed, this is one of the reasons why we witness the emergence of alternative standard-setting bodies such as the ISEAL Alliance or GlobalG.A.P., where such interests find expression and can voice their concerns and interests. Accordingly, this finding by the Appellate Body may open the door for more diversity within the ISO in the medium run.

Effectiveness and relevance is the fourth principle set out in the Decision, which requires that ISSBs (1) take into account relevant regulatory or market needs, and scientific and technological developments in the elaboration of standards; (2) put in place procedures aimed at identifying and reviewing standards that have become obsolete, inappropriate or ineffective; and (3) establish or maintain communication channels with the WTO. Regarding market relevance vis-à-vis a specific work item, the Directives include an important set of substantive guarantees to ensure the market

174. See supra US - Tuna II, note 18 , at 9383.

175. Id. ๆ 384. 
relevance of new proposals for standards development. As mentioned earlier, the burden of proof lies with the P-member that proposes new work. The ISO TMB had established a global relevance policy as early as in 2003, worried that its relevance for TBT purposes may be questioned. Interestingly, the Directives suggest that the adoption of the TBT "placed an obligation on ISO to ensure that the International Standards [sic] it develops, adopts and publishes are globally relevant." (Emphasis added). ${ }^{176}$ The TMB understands what is at stake: a standard failing to meet the requirements of the TBT Committee Decision may be challenged as creating a barrier to trade.

Global relevance is defined within ISO as "required characteristics of an International Standard that it can be used/implemented as broadly as possible by affected industries and other stakeholders in markets around the world." ${ }^{\prime 177}$ As the intent is to capture and accommodate market dynamics through ISO standard-setting, regional or national differences would not normally be taken further unless they are essential (e.g., related to climate differences, anthropometry, or embedded technological infrastructures) and thus are typically not subject to change and adaptation. Where such concerns are present, the ISO approach on introducing a unique international solution through standard-setting would not hold; rather, these concerns would need to be addressed.

Again, within ISO, it is for the TC, and more specifically, the PMembers, to examine and confirm the global relevance of a given (new) work item and raise any essential differences that should be included in the standards. The latter should be presented to the other P-members of the relevant TC for approval as early as possible and at the latest at the Committee draft stage. ${ }^{178}$ Provided that essential differences eventually form part of the draft international standard, negative votes cannot be premised solely on the fact of such an inclusion.

As noted earlier, there do not seem to be any compelling reasons for limiting to P-members the right of raising essential differences. Furthermore, there is no review mechanism regarding the approval (or not) of such

176. ISO/IEC Directives, supra note 96, at annex SM.1. The Annex reproduces the document on ISO/TMB Policy and Principles Statement - Global Relevance of ISO Technical Work and Publications. It reiterates the list of substantive criteria that determine the global relevance of a given standard to be found in the TBT Committee Decision (effectively respond to regulatory and market needs; respond to scientific and technical developments in various countries; not hinder fair competition or innovation; and be performance-based).

177. Id. annex SM.2.

178. See ISO/TMB Implementation Guidance - Global Relevance of ISO Technical Work and Publications, at 10, annex 2 (2004), http://www.iso.org/iso/iso_tmb_implementation_guidance_global relevance.pdf [https://perma.cc/ U5MM-4892] (last visited on Feb. 18, 2017). 
requests within a given $\mathrm{TC}$ (other than the general appeal mechanism within ISO, the use of which is, again, largely limited to P-members). The TMB does not seem to play any immediate role here as a more neutral control mechanism. ${ }^{179}$ Indeed, depending on the dynamics within a TC, undermining the importance of essential differences raised may be the prevailing stance: intuitively, most P-members would have no incentive to create loopholes within a given standard. Increased compliance costs or delays in finalizing the Committee draft may be some of the reasons that would justify such an opposition by P-members within a TC.

At the post-adoption stage, ISO includes a review mechanism of standards and technical specifications. However, a systematic impact assessment instrument does not form part of the ISO standard-setting system. Nor is such a requirement imposed by the TBT Committee Decision. However, the possibility of including such a requirement was proposed as a useful tool to ensure the continuous relevance and efficacy of a given standard. ${ }^{180}$ For instance, competing SSBs such as the ISEAL Alliance adopted an Impacts Code that requires the assessment of repercussions on various fields both during the drafting and after the adoption of ISEAL sustainability standards.

The fifth principle of the Decision is coherence, which, pursuant to the Decision, points to the need for cooperation and coordination with other relevant ISSBs to avoid duplication or overlap. Thus, the concept of coherence does not refer here to the standards and standard-setting processes within a single ISSB, but rather the appropriate relationship among institutions with similar functions. ISO has such mechanisms in place, at least with respect to IEC at the international level, ${ }^{181}$ but also $\mathrm{CEN}$ at the regional level. ${ }^{182}$

179. See id. at 3-4. The document suggests that, in case of doubt and absent a resolution of the concern at the TC level, the TMB may be asked to review the details to provide advice/direction to the relevant TC. However, this is an informal, conciliatory role that the TMB may play with no reference as to when and how the TMB will indeed intervene.

180. See TBT Committee, Principles of International Standard Setting, supra note 172, at 3.

181. Annex B of the ISO/IEC Directives suggests that ISO and IEC together form a system for international standardization as a whole. Indeed, these two ISSBs account for about $85 \%$ of international product standards. See Tim Büthe, Engineering Uncontestedness? The Origins and Institutional Development of the International Electrotechnical Commission (IEC), 12 BUS. \& POL. 1, 5 (2010). Annex $\mathrm{B}$ describes precisely how work is allocated and liaison works between the two institutions. For the most sensitive, unresolved questions of coordination and work allocation the ISO/IEC Joint Technical Advisory Board may be consulted.

182. See The Agreement on Technical Cooperation Between ISO and CEN (Vienna Agreement), $\uparrow$ 5 (1991), http://isotc.iso.org/livelink/livelink/fetch/2000/2122/3146825/4229629/4230450/4230458/ 01_Agreement_on_Technical_Cooperation_between_ISO_and_CEN_(Vienna_Agreement).pdf?nodei $\mathrm{d}=4230688 \&$ vernum $=-2$ [https://perma.cc/3R3R-MD66]. This Agreement becomes operational through 
The Vienna Agreement and the subsequently adopted guidelines are monitored by the Joint Co-ordination group of the TMB and the CEN Technical Board (CEN/BT) and entail two options for collaborative standard-setting: the ISO lead and the CEN lead. Thus, while recognizing the primacy of international standards, this cooperation agreement results in the CEN becoming a decentralized agent (and preferred strategic partner) for the development of new standards. The Guidelines provide that, if the expected results are not achieved, ISO or CEN can proceed separately in the development of standards. In addition, when the CEN lead is opted for (and for this a simple majority of the non-CEN P-Members of the ISO TC is required), CEN should ensure the due process rights of non-CEN ISO members (for instance, by adequately responding to their comments). Under certain circumstances, and regardless of whether ISO or CEN were the lead organization, a decision may be reached to approve a given standard within ISO and CEN in parallel.

The last principle that the Decision identifies is addressing the concerns of developing countries. The Decision recognizes the challenges of ensuring effective participation in international standard-setting that these countries have diachronically faced. Notably, the Decision requires that "tangible" ways of effective participation of developing countries must be sought. However, arguably in line with the soft, hortatory for the most part, language that is used in the WTO provisions relating to special and differential treatment for developing countries, the Decision defines this requirement in a negative manner in that it requires no de facto exclusion from the standardization processes within the relevant ISSB.

As noted earlier, ISO has developed an action plan for developing countries for the period of 2016-2020. This is the third five-year action plan adopted by ISO, which succeeded the triennial programs adopted in the previous decade. ${ }^{183}$ DEVCO monitors the proper execution of the action plan. Nevertheless, the structure of DEVCO may not be the most adequate one for accommodating developing countries' concerns. ${ }^{184}$ The current action plan entails a targeted approach with five intended "outcomes," including increased participation in the technical work. The plan, however, remains relatively vague in several instances, whereas under certain outputs, it appears that the language used is hortatory.

the Guidelines for the implementation of the Agreement on Technical Cooperation between ISO and CEN (the Vienna Agreement), 6th ed., January 2014.

183. The execution of the action plan is among the key priorities of the ISO Strategic Plan 20162020. See ISO Strategy 2016-2020, 2015, at https:/www.iso.org/files/live/sites/isoorg/files/archive/ pdf/en/iso_strategy_2016-2020.pdf [https://perma.cc/9NPL-AL4U].

184. Recall that many developing countries are only O-members in DEVCO, which undermines their chances for meaningful participation and influence. 
Under these circumstances surrounding developing country participation, the direction that the action plan takes, even if unsatisfactory, appears eventually to be the correct one: actions for the strengthening of domestic standardization (including deliberation and multi-stakeholder input gathering or reinforcing the national quality infrastructure) processes are coupled with actions within ISO, most prominently the twinning program. However, measuring performance at the end of each action plan is a prerequisite for identifying tangible benefits in drawing regular action plans of this type.

Twinning can be more effective than many other technical assistance initiatives designed within the ISO Committee on developing country matters (DEVCO). However, there are some worrisome signs relating to this initiative: a recent survey showed that more than fifty percent of these agreements are informal despite the existence of an ISO template. ${ }^{185}$ It also showed that the main beneficiaries of such agreements were the Chinese (23 agreements) and Brazilian (9 agreements) SSBs (as of September 2013). ${ }^{186}$

While not perfect, twinning is a very promising instrument that may force changes in perceptions and reforms in the domestic SSBs involved. It can lead to more serious efforts for mutual understanding, respect, and eventually trust. It is quite telling that ISO national standards bodies from developing countries largely remain governmental agencies, whereas one would expect that private and multi-stakeholder participation leads to a hybrid form of representation, acknowledging the fact that, in most cases, technical knowledge and know-how is vested with private, industry-driven actors. Twinning may instigate reflection and expeditious action towards the creation of more efficient structures with a view to becoming more eloquent, outspoken, and confident at the ISO level. This will be beneficial for the ISO as well because more voices may raise fundamental issues of relevance for certain standards (for instance, due to important regional needs and peculiarities). Finally, one cannot emphasize enough the importance of increasing mutual trust and enduring professional relationships among participants in the international standardization process.

All in all, even if the approach vis-à-vis developing countries' participation as expressed in the current Action Plan appears to go in the right direction at first blush, no systematic and rigorous review of the impact

185. To assist in striking such agreements, ISO has prepared a twinning agreement template: Twinning Agreement template, www.iso.org/iso/twinning_agreement_template.doc (last visited Feb. 15, 2017).

186. The study was conducted by the Japanese Standards Association, available at: https://www.jsa.or.jp/datas/media/10000/md_1186.pdf. 
of such programs and plans (for instance, the ISO Action Plan 2005-2010) seems to have taken place to date. ${ }^{187}$ In addition, previous initiatives such as the Forum on Standards Actions in the Global Market (SGM Forum) had mixed results.

The above analysis suggests that, although far from being flawless, the ISO efforts to address standards development-related developing country concerns are going in the right direction, in view of the organization's diachronic structural bias towards the most advanced global standard-setters, that is, the traditional players from developed countries. ISO has made good faith efforts to become more inclusive, but the need for reform is not limited at the ISO level; rather, effective participation is also a function of the level of - and determination for-reforms domestically. In other words, no change in effective participation levels will occur without empowerment of domestic standards development bodies and guarantees for respect of due process rights of stakeholders at the domestic level. It is no coincidence that ISO insists on the six principles being respected not only by TCs at the ISO level, but also by national standards bodies, notably those of openness, transparency, and impartiality.

Overall, ISO activities and processes appear to be guided to a large extent by the six principles enshrined in the TBT Committee Decision, but full compliance cannot be claimed as of yet. It appears that a more thorough review of ISO practices against the principles of the TBT Committee Decision will most likely trigger a reform of standard-setting practices and should be expected to lead to a new approach in transnational standardsetting. Standard-setting 2.0 is bound to happen, as voices for more openness and inclusiveness from those hardly involved to date and other international organizations sharing similar objectives, such as the WTO, multiply.

A remaining interpretive issue of systemic importance is whether failure to comply with one of the TBT principles may be sufficient to question ISO's compliance with the TBT Committee Decision and thus jeopardize the relevance of ISO's standards for WTO purposes. In other words, is the adherence to all principles a precondition for a given ISSB to receive TBT clearance in accordance with Article 2.4 TBT or would a more holistic inquiring exercise of the ISSB's overall activities and procedures have to take place, balancing all existing evidence? In US-Tuna II, the Appellate Body did not seem to exclude the latter possibility, as it observed that "to the extent that a standardizing body complies with the principles and

187. DEVCO appears to be sending questionnaires to beneficiaries of activities implemented under the current Action Plan to assess their impact but it is unclear how these feed into the subsequent action plans. See DEVCO 47th meeting - Working Documents, St. Petersburg, Sep. 16-17, 2013, at 40. 
procedures that WTO Members have decided 'should be observed' in the development of international standards, it would be easier to find that the body has "recognized activities in standardization.",188

A proper reading of the Appellate Body's approach suggests that no mechanical analysis of compliance of ISO (or, indeed, of any ISSB at issue) with the six principles of the TBT Committee Decision would be opted for. Rather, a broad assessment of the practices of the relevant ISSB would be made, along with an analysis of the procedures that led to the adoption of the standard at hand before a final decision can be reached as to the relevance of such a standard for TBT purposes.

Taking ISO as an example, then, the WTO adjudicating bodies would have a dual mission: first, to examine whether ISO practices comply with the Decision in general, and, second, whether the Decision was respected when the specific ISO standard at issue was adopted. This would be the direct implication and natural consequence of the fact that, as submitted earlier, the characteristics of the process followed for the eventual adoption of a given ISO standard affect the ultimate authority and value of that standard.

\section{CONCLUSION}

International standardization is key for economic growth and innovation. In addition, economic evidence suggests that standardization has contributed to trade much more than any trade agreement could ever have. ${ }^{189}$ ISSBs constitute a forum that fosters the competition of ideas, whereby one of them (or a combination thereof) will become the reference point for production processes and methods globally. Technical merit and noneconomic considerations battle for relevance, whereas the relevant SSBs try to ensure their smooth functioning. As such, clashes of conflicting values can easily lead to a paralysis of their activities. It is important to acknowledge that ISO has no easy mix of tasks to execute in this respect, pending between identification of technical superiority and guaranteeing openness and transparency.

When it comes to procedural and substantive safeguards in global institutions, setting the bar too high may be misleading, as it does not capture the idiosyncrasies of hybrid, voluntary-based institutions active at the transnational level. ${ }^{190}$ Rather, ensuring a fair representation of a wide array of affected interests in the standard-setting process should be the objective

188. See US - Tuna II supra note 18 at, $₫ 376$, WTO Doc. WT/DS381/AB/R (adopted May 16, 2012).

189. See Daniel Bernhofen, Zouheir El-Sahli \& Richard Kneller, Estimating the Effects of the Container Revolution on World Trade, 98 J. INT'L ECON. 36, 46 (2016).

190. See Andrew Moravcsik, Is There a "Democratic Deficit" in World Politics? A Framework for Analysis, 39 Gov'T \& OpPOSITION 336 , 337 (2004). 
of any transnational rule-maker. At the institutional level, responsive statutes and internal regulations should be in place, allowing for adjustments when needed and ex post control.

Technocratic legitimacy may not be sufficient to discharge ISO of the obligations that it has as the global leader in standard-setting. As described earlier, ISO has undertaken serious good faith efforts to address complaints regarding its standard-setting processes; notably with respect to participation, relevance, and coherence. Its observer status at the TBT Committee also helped gauge the pulse of those WTO Membersdeveloping countries for the most part—who believe that access to ISO standard-setting is still intractable.

The world of voluntary standards has evolved to affect more parties globally than initially expected. The early immunity that it enjoyed at the international level due to its non-public nature has eroded after the "multilateralization" of the TBT Agreement. The voluntary character of standards remained, but the advent of the WTO changed the impact of international standards for good. Regulatory convergence and reduction of non-tariff barriers would now pass through the adoption of these standards, which were regarded as authoritative expressions of technical excellence internationally. Indeed, the TBT took an orthodox view vis-à-vis international standards: standards improve product efficiency and facilitate trade, notably when adopted at the international level, as compliance costs are reduced. Therefore, adherence to international standards becomes a necessary condition for the very attainment of the TBT objectives.

Importantly, no grandfathering would be accepted: as established by the WTO Appellate Body in EC-Sardines, even standards adopted before the creation of the WTO would be considered to assess the consistency of the regulatory instruments of a given WTO member with the TBT. Noncompliance with these mandatory benchmarks for domestic technical regulations would raise suspicions as to the good intentions of governmental intervention.

The ISO and the WTO run parallel lives and pursue similar missions focusing on improving market access in a cost-effective manner. The emergence of new players in the international scene seeking to shape rulemaking in international affairs more actively has played no less a significant role in increasing the impact of international standard-setting. Previously run in essence by the developed world, the international standardization community attracted the interest of an ever-increasing number of parties and thus had to become more inclusive without, however, putting into jeopardy its effectiveness with respect to consolidating technological advances. Admittedly, no empowerment of new ISO members is possible without 
effective participation. Therefore, strengthening procedural rights is the gateway to more inclusive and representative international standards. In turn, only higher levels of participation can reduce the knowledge gap between developed and developing countries.

This much-needed reform in ISSBs and the ISO has been the result of developments within the TBT Committee, most notably the adoption of the TBT Committee Decision in 2000. Analysis of this Decision and its potential impact has been surprisingly scarce to date. It is the first time in the WTO that the delegation of regulatory power to ISSBs was made conditional upon adherence to a series of principles, mainly of procedural due process in nature. This Decision was vested with substantial legal value through the US - Tuna II ruling, showing the potential "bite" of WTO adjudication as an ex post legitimating device for international standardization: output by standards organizations will be critically reviewed and perhaps discarded if it fails to satisfy the principles set out in the Decision. The principles are quite demanding and few ISSBs would manage to meet each one of them and in a cumulative manner. ${ }^{191}$

Discussion of ISO standards has been a rare phenomenon in WTO adjudication. ${ }^{192}$ One reason for this may be that WTO Members consider ISO to function relatively well, in a transparent, open, and efficient manner. However, as suggested in this article, closer scrutiny of ISO may prove otherwise. Using the example of ISO, this article critically reviewed the procedural and substantive guarantees that are in place to ensure that international standards adopted in international standardization fora are in line with basic tenets of due process or transparency. One of the most powerful findings of this article is that the reform of ISO processes has not come full circle yet; on the contrary, ample room for improvement exists. ISO has several steps to take to align with the telos of the TBT Committee Decision but also with contemporary demands relating to global governance institutions.

The US - Tuna II ruling can potentially herald a new era of international co-operation in international standard-setting based on solid grounds relating to due process, consultation, reasoned regulatory-making, inclusion, and technical excellence, particularly in light of the Appellate Body's findings. At the same time, US - Tuna II was confined to a discussion of practices and institutional structures of a regional SSB, whereas it discussed shortly only

191. See also Robert Howse, The World Trade Organization 20 Years On: Global Governance by Judiciary, 27:1 EUR. J. INT'L L. 9, 56 (2016).

192. Only a few WTO Panel Reports have touched upon specific ISO standards. See, e.g., Panel Report, European Communities - Measures Affecting Asbestos and Products Containing Asbestos, WTO Doc. WT/DS135/R (Sep. 18, 2000). 
one of the six principles identified in the TBT Committee Decision. Thus, nothing would prejudge the outcome of a dispute in which an ISO standard would be at issue.

This article, however, argued that the WTO adjudicating bodies will be no less willing to critically review the ISO standard-setting processes. This is also in line with a more critical view of international standard-setting, this time by the multilateral trading regime qua a parallel horizontal system. Evidence about insufficiently inclusive and open procedures throws shade against ISSBs and the ISO is no exception. Current discussions in NAMA negotiations only exemplify this discontent. And, while the present stalemate in the WTO negotiations may lead some to argue against the relevance of the views expressed within the WTO, it is submitted that essentially similar views are to be found in the negotiating texts of preferential trade agreements, so-called "mega-regionals" such as the TTIP'193 or the TransPacific Partnership (TPP). ${ }^{194}$

Such a critical view of international standardization activities is a welcome development if it leads to an era of more representative international standards. It is also indicative of a broader trend by public authorities to guarantee the importance of due process rights of all stakeholders in standard-setting activities. ${ }^{195}$ However, it is argued that a new conceptual framework is needed to inform the development of international standards in ISSBs. This new framework will inevitably build on the TBT Committee Decision, but shall also include other criteria relating to sustainability ${ }^{196}$ and inter-institutional sensitivity as well as cooperation with relevant international organizations and NGOs. Depending on the subjectmatter (for instance, to ensure that a given standard also is in line with

193. See the EU's textual proposal for a chapter on technical barriers to trade, Transatlantic Trade and Investment Partnership art. 6:3 (made public on January 7, 2015).

194. The TPP text is even more explicit than the EU's proposal under the TTIP, calling for the use of the TBT Committee Decision regarding international standards. See final text of the Trans-Pacific Partnership, Chapter 8 (Technical Barriers to Trade), art. 8.5. Despite the US withdrawal from the deal, the remaining TPP members will soon meet to see the prospects for implementing the deal among them.

195. Failure to protect such rights within SSBs may lead to anti-competitive behavior. See, Communication from the European Commission, Guidelines on the applicability of Article 101 of the Treaty on the Functioning of the European Union to Horizontal Co-operation Agreements, [2011] O.J. C 11/01, paras 280ff; US National Cooperative and Production Act (NCRPA), 15 U.S.C. $§ 4301(a)(8)$. Early on, the US Supreme Court underlined the importance of procedural safeguards within SSBs. See Allied Tube v. Indian Head, Inc., 486 U.S. 500, 501 (1988).

196. ISO has recently published guidelines addressing sustainability in standards development. The guidelines are intended to encourage the examination of issues relating to sustainability during all stages of standards development within ISO. Importantly, the guidelines provide that the lack of considering sustainability issues in the development of a given standard can validly justify the revision of that standard and call for the involvement of knowledgeable experts in such a revision: See ISO Guide 82:2014. 
pertinent labor or human rights), consumers and trade unions shall also be involved.

Indeed, from a normative point of view, for a standard to be regarded as a genuinely international standard, additional, but at the same time more concrete, criteria would need to be developed. ISO seems to be laser focused on output legitimacy, which is a fairly appealing approach for an organization dealing with technical standards. However, input legitimacy (allowing interested parties to be heard at an early stage in the process), early notification procedures, and appropriate mechanisms for review that are easy to understand and use should be inextricably associated with the functioning of any organization that aspires to be a meta-regulator of technical matters at the international level. At the post-adoption stage, systematic impact assessment should be in place, allowing any ISO member to raise the need for revision.

Additionally, in line with the dual character of ISO's mission (that is, technical and political), scientific rigor, relevance, and technical excellence cannot be left outside any analysis as to the international character of a given standard. Furthermore, ISO has yet to make decisive steps towards more openness vis-à-vis the public. Information on standard-setting processes and on disciplinary cases or appeals is not readily available. This undue secrecy may harm the public image of ISO. Interestingly, even non-technical information produced by ISO such as guides or recommendations of a nontechnical nature are only available with a fee.

To be sure, ISO's business model, which is based on copyright protection and charging a fee for full access to the text of a standard, has been criticized because its application to standards referenced in legislation defies any notion of public openness and transparency. ${ }^{197}$ However, ISO could soften some of this criticism by offering access to non-technical documents such as guides or recommendations, all the more because many of them are made available by national SSBs. ${ }^{198}$

197. In a recent case that discussed the question of copyright for model building codes incorporated in legislation, the US Court of Appeals for the Fifth Circuit drew a line vis-à-vis standards created by SSBs suggesting that the latter are not created for the sole purpose of being used in binding legislation. Rather, the relevant public authorities later decide to refer to such standards in their legislation, i.e. incorporate them by reference. The Court seemed to favor the existence of copyright protection in such cases although it denied such protection to the model codes at issue which were created with the sole purpose of becoming part of legislation, which then should exclude their copyrightability. See Veeck v Southern Building Code Congress Int'1, Inc., 293 F.3d 791, 804-05 (5th Cir. 2002)(en banc).

198. In the EU, the issue of access to the text of standards referenced in EU legislation (so-called 'harmonized standards') is at the epicentre of the reform of the EU standardization processes also due to jurisprudential developments. In the recent Elliott case, the CJEU found that EU harmonized standards form part of EU law, opening the door for judicial action against the substantive content of standards but also against any denial by SSBs of access to these documents. See Case C-613/14, James Elliott Constr. 
Finally, ISO also has an educational mission to accomplish that has often been neglected. The scratch line is not the same for all ISO members and this shows already in the distribution of technical work within ISO. Only by reducing the knowledge gap between ISO members can one hope for the creation of standards that largely reflect global preferences. This is a matter of political will and heavy investment: DEVCO regularly raises funding in ISO meetings but urges the most sophisticated members to increase their efforts and ensuing investment. It is a matter of fairness, but also a strategic matter for ISO: what would happen if the newly emerging economies which start having significant monopsony power experiment with the creation of their own standards that diverge from ISO standards, based on arguments of effective exclusion within ISO? This could have undesirable consequences for all ISO members and everyday business and trade. Further research on the functioning of ISSBs would be necessary to shed light on best practices and policies as well as procedural deficiencies that perpetuate an unbalanced standard-setting landscape at the international level.

Ltd. V. Irish Asphalt Ltd., ECLI:EU:C:2016:821, paras. 38-43 (2016); see also, Case C-630/16, Anstar, ECLI:EU:C:2017:971, para. 32 (2017). 